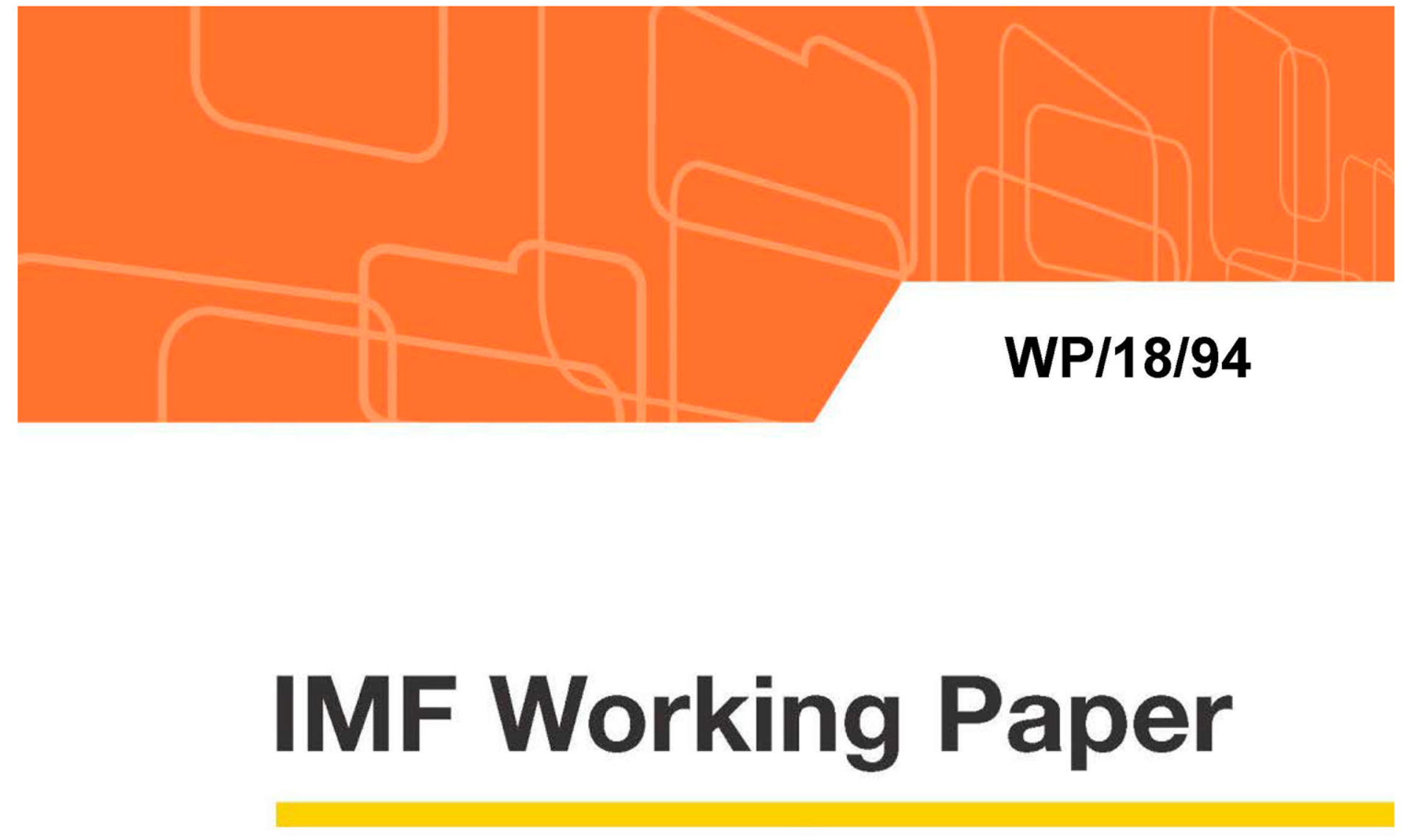

\title{
A New Action-based Dataset of Fiscal Consolidation in Latin America and the Caribbean
}

by Antonio C. David and Daniel Leigh

IMF Working Papers describe research in progress by the author(s) and are published to elicit comments and to encourage debate. The views expressed in IMF Working Papers are those of the author(s) and do not necessarily represent the views of the IMF, its Executive Board, or IMF management. 


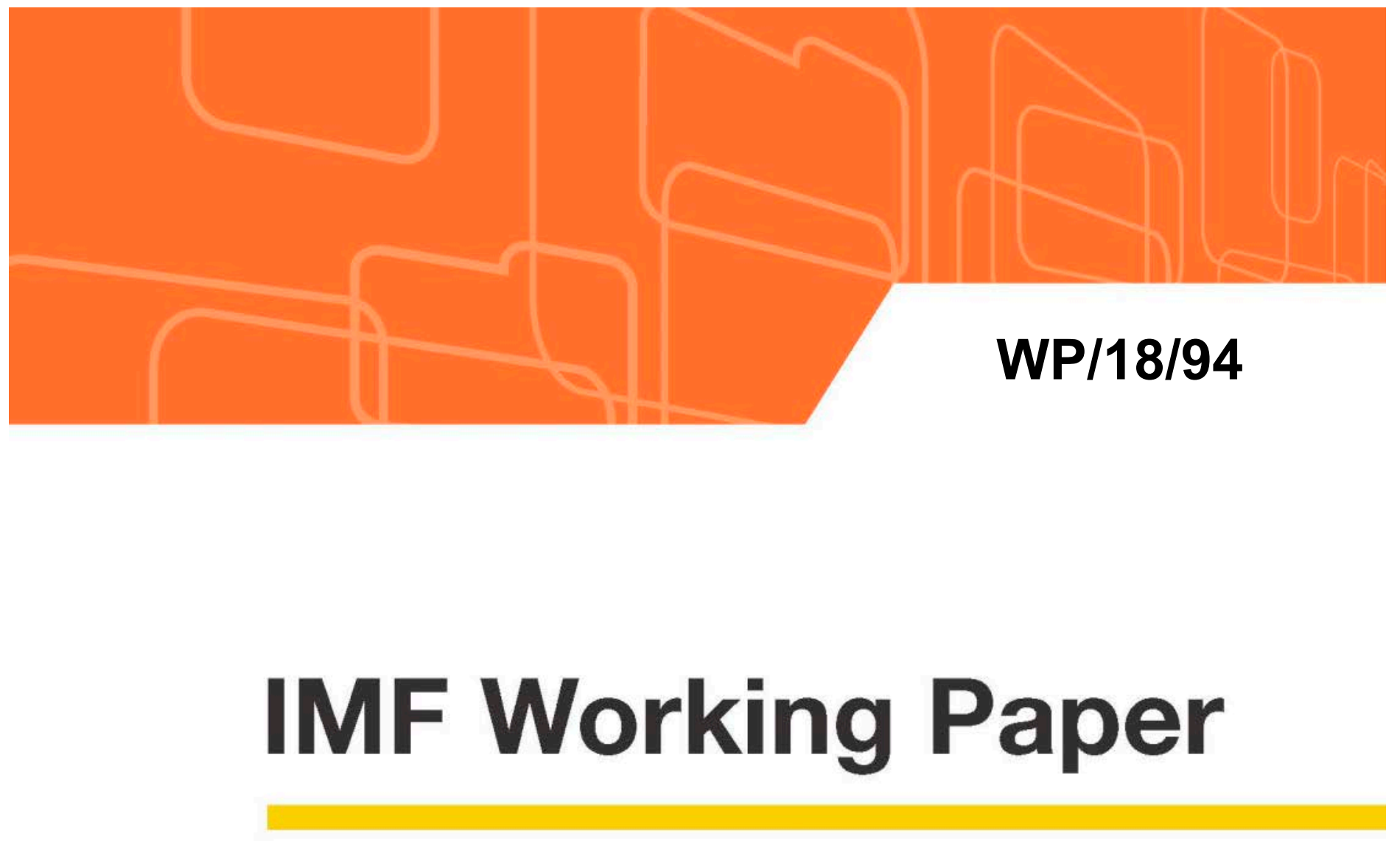

\title{
A New Action-based Dataset of Fiscal Consolidation in Latin America and the Caribbean
}

\author{
by Antonio C. David and Daniel Leigh
}

IMF Working Papers describe research in progress by the author(s) and are published to elicit comments and to encourage debate. The views expressed in IMF Working Papers are those of the author(s) and do not necessarily represent the views of the IMF, its Executive Board, or IMF management.

$$
\text { I N T E R N A T I O N A L M O N E T A R Y F U N D }
$$




\title{
IMF Working Paper
}

Western Hemisphere Department

\section{A New Action-based Dataset of Fiscal Consolidation in Latin America and the Caribbean ${ }^{1}$}

\author{
Prepared by Antonio C. David and Daniel Leigh
}

Authorized for distribution by Hamid Faruqee

April 2018

\section{IMF Working Papers describe research in progress by the author(s) and are published to} elicit comments and to encourage debate. The views expressed in IMF Working Papers are those of the author(s) and do not necessarily represent the views of the IMF, its Executive Board, or IMF management.

\begin{abstract}
This paper presents a new database of fiscal consolidations for 14 Latin American and Caribbean economies during 1989-2016. We focus on discretionary changes in taxes and government spending primarily motivated by a desire to reduce the budget deficit and long-term fiscal health and not by a response to prospective economic conditions. To identify the motivation and budgetary impact of the fiscal policy changes, we examine contemporaneous policy documents, including Budgets, central bank reports, and IMF and OECD reports. The resulting series can be used to estimate the macroeconomic effects of fiscal consolidation for these economies.
\end{abstract}

JEL Classification Numbers: E62, H20, H5, H6

Keywords: Fiscal policy, taxation, government expenditure

Author's E-Mail Address: adavid@imf.org, dleigh@imf.org

\footnotetext{
${ }^{1}$ We are grateful to Sebastian Acevedo, Roberto Cardarelli, Jaime Carrera, Aliona Cebotari, Valentina Flamini, Frank Fuentes, Roberto Garcia-Saltos, Dmitry Gershenson, Jaime Guajardo, Izabela Karpowicz, Nicole Laframboise, Frederic Lambert, Carola Moreno, Abelardo Pachano, Magali Pinat, Daniel Rodriguez, Pedro Rodriguez, Rene Tapsoba, Iulia Teodoru, Saji Thomas, Joyce Wong, Irina Yakadina, as well as the members of the different IMF country teams for helpful comments; and to the staff of the Joint Bank-Fund Library for their support in locating the historical records cited in the paper.
} 


\section{INTRODUCTION}

This paper constructs a new database of fiscal consolidation measures taken by the governments of 14 Latin American and Caribbean (LAC) economies to reduce budget deficits during 1989-2016. It builds on earlier work by Devries et al. (2011) that identified such fiscal consolidation measures for 17 OECD economies.

Numerous studies on the effects of fiscal consolidation identify fiscal policy actions using statistical concepts, such as the increase in the cyclically-adjusted primary budget balance (CAPB). However, as explained in Devries et al. (2011) and elsewhere, using the CAPB - or related methods based on cyclical adjustment - to estimate the macroeconomic effects of fiscal consolidation is problematic.

First, cyclical adjustment methods suffer from measurement errors that are likely to be correlated with economic developments. Cyclical adjustment typically fails to remove the impact of sharp swings in economic activity and asset or commodity prices from fiscal data, resulting in changes in the $\mathrm{CAPB}$ that are correlated with economic activity, but are not necessarily linked to policy actions. For example, a stock market boom improves the CAPB by increasing capital gains and cyclically-adjusted tax revenues and is also likely to raise domestic demand. ${ }^{2}$ A commodity price boom may stimulate private investment while also raising cyclically-adjusted government revenues.

Second, even if the change in the CAPB accurately reflects discretionary changes in fiscal policy, those can be motivated by a desire to respond to cyclical fluctuations, raising reverse causality concerns. These shortcomings complicate efforts to estimate the macroeconomic effects of fiscal consolidation, and are likely to bias the analysis toward finding evidence of expansionary effects.

To avoid these problems, we identify fiscal actions using a narrative approach similar to that of Romer and Romer (2010). In particular, we examine policymakers' intentions and actions as described in contemporaneous policy documents, and identify measures motivated primarily by deficit reduction and long-term fiscal health. As Romer and Romer (2010) explain, such fiscal actions represent a response to past decisions and economic conditions rather than to prospective conditions. As a result, they are unlikely to be systematically correlated with other developments affecting output in the short term, and are thus valid for estimating the macroeconomic effects of fiscal consolidation. ${ }^{3}$

\footnotetext{
${ }^{2}$ A number of recent papers (Liu et al., 2015; and Yang et al., 2015) have tried to mitigate this problem by building CAPB indicators that attempt to address the influence of asset price fluctuations.

${ }^{3}$ For a discussion of the potential pitfalls of the narrative approach see Ramey (2016), Jordà and Taylor (2015), and Escolano et al. (2014).
} 
In addition, we also include in the dataset policy actions motivated by other long-term objectives that could include tax changes aimed at reducing inequality, improving incentives, increasing efficiency or based on a philosophical belief in the benefits of small government, as discussed in Romer and Romer (2010). On some occasions, these actions would enter the database with a negative sign if they imply expansions in the budget deficit (in the case of tax cuts, for example). However, there are only a relatively small number of such episodes ( 9 observations) in our sample.

More generally, it is important to note that we only include in the dataset fiscal measures that were in fact implemented. If measures were announced but did not come into effect, we do not include them in the database. For example, the government of Costa Rica announced a consolidation package in 1990 that in addition to revenue measures amounting to 1.5 percent of GDP, also envisaged 2 percent of GDP in expenditure cuts. As the latter were not implemented, we only include the revenue measures in the dataset. Occasionally, announced measures are only partly implemented or are implemented with delays and the coding of the budgetary impacts in the dataset take these features into account.

The historical sources we examine include reports from multilateral institutions such as IMF staff reports and OECD Country Economic Surveys; as well as budget-related documents (such as several issues of the Informe de Finanzas Publicas for Chile and Paraguay, the Marco Fiscal de Mediano Plazo report for Colombia, the Criterios Generales de Política Económica for Mexico, and the Marco Macroeconomico Multinaual report for Peru) and reports by Central Banks. In some instances, these primary sources were complemented by information from working papers or other research documents.

Based on this approach, our sample includes 76 fiscal policy adjustments in 14 LAC economies between 1989 and 2016. The data are presented at an annual frequency. The countries included in our sample are Argentina, Bolivia, Brazil, Chile, Colombia, Costa Rica, Dominican Republic, Ecuador, Guatemala, Jamaica, Mexico, Paraguay, Peru, and Uruguay. The average consolidation size is 0.9 percent of GDP with a standard deviation of about 1 percentage point. A quantitative comparison of our series of fiscal consolidations and the change in the CAPB is provided in Carrière-Swallow, David, and Leigh (2018).

The paper is organized as follows. Section II describes how we determine the motivation of fiscal actions and their budgetary effects from the historical record. Part III provides detailed citations for each case of fiscal consolidation that we identify. Finally, the last section tabulates the new series of fiscal consolidation, provides a breakdown into spending and tax measures, and discusses some descriptive features of the narrative dataset. 


\section{Methodology}

\section{A. Motivation of Measures}

A key step in the narrative analysis is to examine policymakers' intentions to ensure that the tax and spending measures that we include in our database were motivated primarily by the desire to reduce the budget deficit and long-term fiscal health and not by a response to prospective economic conditions. The documents for the 14 LAC countries in our sample indicate three principal motivations for discretionary fiscal actions: a desire to reduce the budget deficit to shore up government financial sustainability; a desire to offset a sharp economic contraction, including in connection with a financial crisis, that reduces government revenue; and a desire to restrain domestic demand for cyclical reasons.

For the afore-mentioned reasons, we focus on fiscal consolidation measures based on a desire to reduce the budget deficit, as in Devries et al. (2011). Costa Rica in 2016 provides an example of such a policy change. The authorities introduced austerity measures to reduce the deficit as part of a gradual path toward fiscal sustainability, and not because there was a need to counter an unexpected economic contraction or the risk of economic overheating. Another example is the consolidation that occurred in Colombia in 2016, which involved cutting spending not to react to a recession or reduce the risk of economic overheating, but because policymakers wanted to comply with the fiscal rule and saw it as a prudent policy change with potential long-term benefits. If consolidation is motivated primarily by restraining domestic demand or in response to an economic contraction, we note its occurrence in footnotes in the paper, but do not include it in our database. By the same token, we record fiscal consolidation in our database even if it is followed by an adverse shock and an offsetting countercyclical discretionary stimulus.

At the same time, if a fiscal consolidation is offset by fiscal actions not primarily motivated by cyclical fluctuations, such as a tax cut motivated by long-run considerations ${ }^{4}$, we compute the sum of the measures and conclude that consolidation occurred if the overall change in policy yields budgetary savings. For example, if spending cuts motivated by deficit reduction were fully offset by tax cuts associated with long-run considerations, we would conclude that no fiscal consolidation occurred. A concrete counterpart to these hypothetical examples is the tax reform approved by Chile in September 2014 to raise 3 percent of GDP in revenue by 2018. While 1 percent of GDP of the additional revenues was allocated to close the structural deficit, the rest was used to finance additional expenditure linked to the structural reform agenda (education and health), therefore the latter part of budgetary impact of the reform is not included in the dataset.

\footnotetext{
${ }^{4}$ As previously discussed, long-run considerations could include for example, measures aimed at reducing inequality, improving incentives, increasing efficiency or based on a philosophical belief in the benefits of small government (Romer and Romer, 2010).
} 
In addition, there are a small number of cases of fiscal actions that imply expansions in the budget deficit that are motivated by long term objectives. Whenever such fiscal actions occur, we record them in the dataset with a negative sign. The reduction in corporate income tax rates in Paraguay in 2005 and 2006 would be an example of such actions. An additional example, would be the case of Chile in 2008, where the government decided to reduce the level of the structural fiscal balance from 1 percent GDP to 0.5 percent of GDP considering that the various long-term fiscal risks that justified the original target had been mitigated.

\section{B. Budgetary Effects}

The sources used to construct the narrative consolidation episodes are historical documents that present retrospective and prospective descriptions of fiscal policy actions, including estimates of their likely budgetary impact. These documents also provide evidence on the motivations behind a given policy action at the time that decisions were taken. The documents used include reports from multilateral institutions such as IMF staff reports (reports for Article IV consultations, Recent Economic Developments reports, and IMF Program documents) and OECD Country Economic Surveys; as well as budget-related documents (such as several issues of the Informe de Finanzas Publicas for Chile and Paraguay, the Marco Fiscal de Mediano Plazo report for Colombia, the Criterios Generales de Politica Económica for Mexico, the Marco Macroeconomico Multinaual report for Peru or the Informe Explicativo y Politica Presupuestaria report for the Dominican Republic) and reports by Central Banks. In some instances, these primary sources were complemented by information from working papers or other research documents.

The measures of the magnitude of fiscal policy changes included in the database rely on estimates of the revenue or expenditure impact of the given policy action at the time of implementation (expressed in annual terms) and at the prevailing level of GDP. As in Devries et al. (2011), temporary policy measures are recorded as having a positive budgetary impact when they come into effect and a negative impact when they expire, whereas a permanent measure is recorded as having a positive budgetary impact when it comes into effect and zero thereafter. For example, Paraguay introduced a temporary export tax on soybeans in 2004 with an expected revenue yield of 0.2 percent of GDP. In that context, we would record a tax hike with a magnitude of 0.2 percent of GDP in 2004. Subsequently, the temporary export tax was eliminated in February 2005 and a revenue loss (negative value) equivalent to 0.2 percent of GDP would be recorded in 2005. If measures were announced but were not implemented, we do not include them in the database. Occasionally, announced measures are only partly implemented or are implemented with delays and the coding of budgetary impacts in the dataset take these features into account, as described in detail in the next section. 
Some authors have expressed concern over the use of multiple sources to obtain estimates of the budgetary impact of fiscal policy actions, arguing that the narrative approach may pool information based on methodologies not entirely compatible (Escolano et al., 2014). Nevertheless, it is important to bear in mind that the ultimate objective of our exercise is to construct a valid instrument for fiscal policy that is correlated with the CAPB, but not related to prospective economic conditions (i.e. exogenous to business cycle fluctuations and shortterm developments). If there's measurement error because multiple sources are used, it should only matter to the extent that it affects these two conditions, which does not seem to be the case. 


\section{COUNTRY-BY-COUNTRY SUMmary OF CONSOLIDATION EPISODES}

In this section, we attempt to provide a sufficient number of quotations and citations from the historical record so that readers can see the evidence behind our conclusions regarding the motivation and budgetary impact of fiscal consolidation actions.

\section{A. Argentina ${ }^{5}$}

\section{Argentina 1996}

Fiscal consolidation consisted of tax hikes of 0.25 percent of GDP. The 1996 Article IV Staff Report (EBS 96/161) explains (p. 9) that, as part of the authorities' program to reduce the fiscal deficit : "... the Government is relying on a package of revenue measures that went into effect in late September 1996 and includes: increases in fuel excises--which would provide about half of the additional revenue; the elimination of some corporate income tax exemptions and loopholes; increases in the rates of the corporate and personal income taxes; increases in tariffs on imports of capital goods consistent with the agreements under MERCOSUR; various actions to raise collections of social security contributions; a reduction in tax rebates for exporters; a removal of subsidies for domestic producers of capital goods; and steps to curtail outlays on family allowances (PM, 15). Also, Congress passed legislation whereby the revenue from the increase in fuel excises will not be shared with the provinces for the next two years (PM, IS). These measures are expected to yield about 1 percent of GDP on an annual basis." Since the measures were implemented in late September, we assign 0.25 percent of GDP to calendar year 1996 and 0.75 percent of GDP to the year 1997.

\footnotetext{
${ }^{5}$ An increase in the VAT rate by 3 percentage points with an estimated revenue yield of 2 percent of GDP was implemented in 1995 with the objective of reducing the fiscal deficit in the context of a loss of confidence in debt markets. In line with Gunter et al. (2017), we consider that this episode was primarily motivated by responding to a fall in confidence and a large capital outflows. Therefore, we do not record it as fiscal consolidation motivated primarily by deficit-reduction and medium-term fiscal sustainability considerations. The 1995 Article IV report (EBS 95/150) states on page 2 that: "Facing a loss of confidence and difficulties in rolling over public sector maturities, in March 1995 the authorities took strong measures to bolster the public finances and provide support to the banking system. ... The measures, which were expected to yield over 2 percentage points of GDP in 1995, included a temporary 3 percentage point surcharge on the value-added tax (VAT) rate, which was exempted from revenue-sharing with the provinces, and a wage cut for higher-paid public employees. The aim was to shift the overall balance in the public finances (excluding privatization receipts) from a deficit of 0.5 percent of GDP in 1994 (and a projected deficit of 1.5 percent of GDP in 1995) to a surplus of 0.7 percent of GDP in 1995, with privatization expected to generate an additional 0.8 percent of GDP". In 2016, the government announced tax hikes amounting to 2 percent of GDP and expenditure cuts of 0.3 percent (see page 11 of IMF country report 16/346 for a detailed description of the measures). But, these policy actions were offset by tax cuts (export taxes) and increases in pension spending. As a result, the federal primary fiscal deficit remained largely unchanged as a share of GDP in 2016 (IMF country report 17/409 Figure 3 and Table 5).
} 


\section{Argentina 1997 \\ The fiscal consolidation initiated in 1996 continued in 1997, with tax measures totaling 0.75 percent of GDP. Fiscal consolidation was motivated by maintaining sound public finances (see entry for 1996 above).}

\section{B. Bolivia ${ }^{6}$}

\section{Bolivia 1995}

Fiscal consolidation amounted to 0.9 percent of GDP, with a tax increase of 1.2 percent of GDP, offset by a spending increase of 0.3 percent of GDP. The tax increase was part of a tax reform presented to Congress in November 1994 with an expected revenue yield of 1.2 percent of GDP in 1995 ( 0.9 percent of GDP considering offsetting expenditure increases), motivated by the need to cover the costs of structural reforms. The Memorandum on

\footnotetext{
${ }^{6}$ While fiscal policy tightening did occur during 1989-94, it was primarily motivated by restraining inflation and responding to balance of payments crises. We therefore do not record it as fiscal consolidation motivated primarily by medium-term fiscal sustainability considerations. For example, the 1989 Article IV Staff Report (EBS/89/209) explains (p. 54) that "Since August 6, 1989 the new government has been implementing policies designed to return the economy to the path outlined in Bolivia's medium-term program described in the memoranda attached to the Letters dated June 30, 1988 and March 1, 1989. These policies aim at economic growth of 2.8 percent for 1989 while seeking to limit inflation to 12.5 percent at end year."

An increase in the VAT rate from 10 to 13 percent in March 1992 as well as an increase in the prices of petroleum products were expected to generate revenues in the order of 1.25 percent of GDP (see the 1992 Article IV consultation staff report EBS/92/137, Page 4percent of GDP). But there were expenditure overruns in 1992 relative to program targets, reflecting higher investment spending and an increase in the public sector wage bill (see 1993 Article IV consultation staff report EBS/93/210). Moreover, fiscal measures amounting to 2.5 percent of GDP in 1998 were more than offset by increased expenditures linked to structural reforms. The 1998 Article IV staff report (EBS/98/153) discusses on page 7 the motivations for the authorities' program for 1998: "Against this background, the authorities' program for 1998 ... aimed to support an increase in economic growth to $4 \frac{1}{2}$ to 5 percent with a further reduction in poverty. The program also aimed to limit the inflationary effects of an increase in indirect taxes and reduce inflation to 6\% percent in 1998". The report discusses the fiscal measures, which included an increase in taxes on domestic petroleum products in December 1997. But these measures could not fully offset the fiscal costs of structural reforms (especially the pension reform), which were expected to reach 5 percent of GDP in 1998.

A fiscal consolidation of 1.7 percent of GDP occurred in 2003 with tax hikes amounting to 0.7 percent of GDP and expenditure cuts amounting to 1 percent of GDP. But it was motivated by the need to stabilize the economy after civil disturbances. The 2003 Request for Stand-by arrangement report (EBS/03/37) discusses the motivations for the policy actions: "The economic program for 2003, in support of which the authorities are requesting an SBA, focuses on stabilizing the economy after the recent civil disturbances and resulting financial instability and laying the basis for a return to growth". In addition, page 9 of the same report lists the key measures adopted in August 2003, which include: i) a new tax code that significantly strengthens the enforcement capabilities of the tax and custom agencies; ii) a tax regularization scheme; iii) a set of modifications to the tax bill (Law 843) that eliminated loopholes, expands tax bases, and limits deductions. Box 2 on page 12 of the 3rd SBA review report (EBS/04/73) presents estimates of the revenue yield of these measures in 2003, which are in the order of 0.7 percent of GDP. The authorities also announced steps to cut expenditures by 1 percent of GDP. As shown in Table 2 on page 25 of the 2006 Article IV consultation staff report (IMF Country Report No. 06/270), these plans were implemented.
} 
Economic and Financial Policies in the 1994 Article IV consultation staff report (EBS/94/228) states the objectives of the policy program on Page 48: "A central element of the Government's program is to increase economic growth by transferring control of the largest public enterprises (oil, electricity, telecommunications, railway, airlines, and smelter companies) to the private sector through a process of capitalization and privatization. The framework law for capitalization that was approved by Congress in March 1994 opens the companies to private investment and provides for the distribution of shares in the enterprises to the accounts of adult Bolivian citizens (to be established in newly created private pension funds). ... The macroeconomic framework for 1995-97 takes into account the costs associated with the capitalization and privatization of the major public enterprises (particularly severance payments) as well as expenditures related to reforms of the education, pension, civil service, and judicial systems. One-time costs of the reforms are estimated. at about $31 / 2$ percent of GDP in 1995 and 1/2 percent of GDP a year in 1996 and 1997, and recurrent costs amount to 0.4 percent of GDP in 1995 and about 1.2 percent of GDP in 1996 and 1997'.

The tax reform measures included an increase in the rate of the transactions tax from 2 percent to 3 percent (effective in February 1995), which is expected to yield additional revenue of 0.9 percent of GDP, as well as an increase in the excise tax on vehicles from 10 percent to 20 percent and higher beer taxes, which became effective in August. The latter two measures are expected to yield 0.3 percent of GDP in 1995 (see page 17 of the 1996 Recent Economic Developments report SM/96/61).

But it appears that the costs of reforms in 1995 was smaller than initially expected due to delays in implementation (see page 1 of the 1996 Recent Economic Developments report $\mathrm{SM} / 96 / 61)$. In fact, overall expenditures increased only by 0.3 percent of GDP. In that context, the increase in revenues contributed to a reduction of the primary deficit of over 1.5 percent of GDP according to WEO data. As the expected increase in revenues was partly offset by an increase in expenditures of 0.3 percent of GDP, we include in the net effect of 0.9 percent of GDP in the dataset.

\section{Bolivia 2004}

Tax hikes amounted to 2 percent of GDP. The tax hikes were part of the program supported by an IMF stand-by arrangement that aimed at reducing the fiscal deficit. The MEFP (p.54) in the $20043^{\text {rd }}$ SBA review report (EBS/04/73) states that: "The 2004 program targets a reduction of the fiscal deficit after grants to 6.1 percent of GDP and to 9.7 percent of GDP before grants, while raising the level of pro-poor spending by 0.6 percent of GDP". The 2004 Informe Economico y Social elaborated by the Ministry for Economic Development also states on page 10 that the policies were geared towards deficit reduction: "In 2004 fiscal policy was oriented towards containing the growth of the deficit and filling the fiscal gap in order to meet the goal of reaching the fiscal target of 6.8 percent of GDP'. 
The measures adopted and their impact in 2004 are described on pages 10 and 11 as well as Box 2 on page 12 of the $20043^{\text {rd }}$ SBA review report (EBS/04/73). In particular, a financial transactions tax was approved in April 2004 and implemented in July with a rate of 0.3 percent on both debits and credits. The overall revenue yield of measures for 2004 was expected to be 2 percent of GDP.

\section{Bolivia 2005}

Tax hikes amounted to 4.1 percent of GDP. The tax increases were motivated by the desire to reduce the deficit and for long run considerations (greater role of the state in hydrocarbons sector). The 20055 th SBA review report (EBS/05/53) presents the motivation for the fiscal measures on page 9: "The authorities aim to reduce the fiscal deficit to $51 / 4$ percent of GDP after grants in 2005, and limit nonconcessional financing to $1 \frac{1}{2}$ percent of GDP". In addition, the May 2005 hydrocarbons law that introduced the IDH tax was consistent with the results of a national referendum conducted in July 2004 . The referendum essentially proposed an enhanced role of the state in the sector (the referendum and its questions are discussed in Box 1 on page 7 of the $20044^{\text {th }}$ SBA review report EBS/04/135). Box 2 on page 14 of the 2005 6th SBA review report (EBS/05/150) provides a discussion of the changes to the hydrocarbons regime in Bolivia in 2005. Interestingly, as stated on page 58 of the 20055 th SBA review report (EBS/05/53), one of the structural benchmarks for the SBA program was the: "Approval by Congress of a Hydrocarbons Law that adopts a strategy on gas exports based on the national referendum including issuing the implementing regulations, regulating the taxation of hydrocarbons and providing an appropriate framework for developing the large hydrocarbon reserves."

The 2005 5th SBA review report (EBS/05/53) outlines some of the fiscal measures adopted in 2005, including increases in fuel excise taxes (in January) with an expected yield of 1 percent of GDP. Crucially, a new direct tax on hydrocarbons (IDH) was introduced in the context of a new hydrocarbons law enacted in May 2005. The law expanded state control over production and commercialization of oil and gas. The IDH tax implied an increase in the level of royalties from 18 to 50 percent of turnover (2007 Article IV consultation staff report SM/07/226, page 7). According to Table 15 on page 43 of the 2006 Memoria Fiscal report elaborated by the Ministry of Finance, the IDH generated 3.1 percent of GDP in revenues in 2005 and 6.1 percent of GDP in 2006. 


\section{Brazil ${ }^{7}$}

\section{Brazil 2015}

Fiscal consolidation amounting to 0.8 percent of GDP consisted of expenditure cuts of 0.5 percent of GDP and tax hikes of 0.3 percent of GDP on a net basis. The measures were motivated by the desire to reduce debt. According to the 2014 Article IV staff report (IMF Country Report 15/161), on page 12: “Over December 2014-January 2015, a new economic team was brought on board with a mandate to strengthen macroeconomic policies and restore credibility. The team announced an ambitious fiscal adjustment strategy to bring the primary surplus to 1.2 percent of GDP in 2015 and to at least 2 percent of GDP in 2016 and 2017. This strategy, together with the ending of policy lending from the treasury to public banks, aims to stabilize and then reduce gross public debt."

Page 13 of the same report presents estimates of the budgetary impact of some of the measures: "On the expenditure side, the government announced (i) reduced benefits and tighter eligibility criteria for survivor pensions, unemployment and sickness benefits, and

\footnotetext{
${ }^{7}$ An adjustment program aimed at reducing very high inflation with 1.5 percent GDP in tax measures and 2.5 percent of GDP in expenditure cuts was implemented in 1990. This episode was determined to be related to cyclical conditions and was not included in the database. According to the 1991 Recent Economic Developments report (SM 91/201) page 26: "In 1990 tax revenue of the Central Administration (excluding earmarked social taxes) increased by 1.5 percentage points of GDP as a result of measures implemented in March". Same report page 30 states that: "Expenditure (excluding outlays shifted to the expanded Social Security Budget) declined by 10.5 percentage points of GDP in 1990 (see Table 1.5); most of the decline ( 8 percentage points) reflected the effect of negative real interest payments on domestic debt and the remainder resulted from cutbacks in current and capital transfers to public enterprises and a number of measures related to the administrative reform". The 1993 Recent Economic Developments report (SM 93/125) sheds light on the motivation of the adjustment program on page 4: "Upon assuming office in March 1990 the new Administration introduced an economic program (the Collor I Plan) that aimed at bringing about a sharp drop in inflation, which had reached 72 percent per month in February".

A fiscal consolidation consisting of tax increases amounting to 1.3 percent of GDP and expenditure cuts of 0.9 percent of GDP (over three years) was implemented in late 1998/early 1999 in the context of a balance of payments crisis. The 2001 OECD Economic Survey report for Brazil has a description of fiscal measures adopted in 1998-1999 on page 58. These measures were deemed to be motivated by cyclical considerations and were not included in the database.

Moreover, important changes to the tax system were approved and implemented in late 2003 and in May 2004 motivated by need to reduce the deficit, but also to increase efficiency. The motivation for the adjustment is discussed by Corbacho in the 2005 IMF selected issues paper (SM/05/83) and also in the 2004 Central Bank of Brazil (BACEN) Bulletin (pages 78-79). The reforms comprised changes in the base (moving them towards a value-added rather than turnover and also incorporating imports) and in the rates for the COFINS and PIS/PASEP taxes. The reform of the COFINS in particular was significantly revenue enhancing, with collections rising by 0.7 percent of GDP in 2004. But these tax increases were also accompanied by exemptions and reductions in other taxes with an estimated annualized cost of 0.5 percent of GDP (see footnote 5 in Corbacho, 2005). In addition, the 2004 BACEN bulletin shows that public expenditures increased by 0.5 percent of GDP in 2004 (mainly public investment and social benefits), which more than offset the net effect of the tax reforms. Biljanovska (2017) in IMF Country Report 17/216 does not identify any episode of fiscal consolidation in Brazil over the period 2001-2015 using the cyclically-adjusted primary balance approach.
} 
salary bonuses for private employees with low earnings, and (ii) the elimination of electricity subsidies (supported by tariff adjustments). The government estimates these measures will yield about 0.5 percent of GDP savings in 2015. On the revenue side, taxes were raised on fuels, household credit operations, car sales, imports, and cosmetics, and a planned revision of PIT brackets was vetoed by the President (yielding 0.4 percent of GDP in total)".

According to the 2015 Central Bank of Brazil Annual Bulletin (Boletim do Banco Central do Brasil, pages 59 to 60), the reductions in energy subsidies and in certain social benefits (Law 13.135 of June 172015 and Law 13.134 of June 16 2015) planned for 2015 were effectively implemented, broadly confirming the estimated cuts discussed in IMF Country Report $15 / 161$. On the revenue side, the report highlights the reinstatement of the IPI tax on several products (Decree 8.393 of January 2015); the increase in the financial transactions tax (IOF) on new loans for individuals (Decree 8.392 of January 2015); and increases in fuel taxes (Decree 8.395 of January 2015), among other policy measures. The report notes on page 60 that: "The expected impact of the measures mentioned was neutralized by the sharp contraction of economic activity...". The Bulletin also indicates (p. 70) that tax cuts of around 3.9 billion reais (about 0.1 percent of GDP) were implemented, partly offsetting the previously discussed revenue measures. Therefore, we assign a net budgetary impact of 0.3 percent of GDP to revenue measures ( 0.4 percent of GDP minus the 0.1 percent of GDP in tax cuts).

The 2016 Article IV report (IMF Country Report 16/348) states on page 7 that: "Fiscal policy was broadly neutral over 2015-16 (not counting the reduction in quasi-fiscal activity) despite cuts in discretionary spending introduced in early 2015. The government started 2015 promising rising fiscal surpluses, and took early adjustment measures, such as the discontinuation of policy lending to BNDES, the modification of some excesses in entitlement programs, and the realignment of electricity tariffs, which staved off the expected flow of subsidies to the sector. However, momentum was not sustained, and policies, including those originating in Congress, were at times expansionary". The same report also states on page 11 that: "In 2015 the non-financial public sector primary deficit reached 1.9 percent of GDP (a far cry from the original target of a surplus of 1.2 percent of GDP), and the overall deficit was 10.4 percent of GDP. The key driver was a fall of 4.8 percent in real revenue collection, which was partially offset by a decline in real expenditures." A large part of the deterioration of the deficit for the public sector in 2015 was also explained by losses on the central bank's foreign exchange swap program as well as the costs of clearing liabilities of the federal government with public banks (on the latter see the 2015 Boletim do Banco Central do Brasil, page 62). 


\section{Chile ${ }^{8}$}

\section{Chile 1990}

Fiscal consolidation based on tax hikes, partly offset by social expenditure increases, amounting on a net basis to 0.5 percent of GDP. The tax increases were motivated by the desire to maintain sound public finances. The 1993 Recent Economic Developments report (SM/93/135) sheds light on the motivation for the tax hikes on page 18: "To maintain public finances on a sound footing while meeting the commitments regarding expenditure, the new Government proposed and Congress approved in mid-1990 tax measures yielding additional annual revenue of about 2 percent of GDP”.

According to the 1990 Article IV staff report (SM/91/50) page 5, the tax hikes approved by Congress in June 1990 were: “... designed to generate revenue of 1.5 percent of GDP in the second half of 1990 and 2 percent on an annual basis". Measures included an increase in the VAT rate from 16 to 18 percent; a change in the base for the corporate income tax (CIT) from distributed to earned profits and an increase in the CIT from 10 to 15 percent starting in 1991. The same report states that: "At least $2 / 3$ of new resources were earmarked to finance additional social expenditures."

Therefore, at least $2 / 3$ of the tax increase would be motivated by an increase in spending and we only consider the impact of the hike that is not offset by this increase (i.e. 0.5 percent of GDP in 1990 and 0.17 percent of GDP in 1991). See also, the Recent Economic Developments report for 1991 (SM/91/58), page 24 and the 1996 Article IV staff report (SM/96/219), page 10 (box 3).

According to the Informe de Finanzas Publicas for 2003 page 50, the estimated impact of the increase in the CIT from 10 to 15 percent was 507 million USD of 2001. The impact of the increase in VAT rates is estimated to have been 134 million USD of 2001. The other major tax change involved an increase in fuel taxes with an estimated impact of 218 million USD of 2001. There were additional measures that increased the tax burden, but also reforms that decreased taxes. The total impact of the tax measures is estimated to be a net increase of 363 million USD of 2001 (not considering the offsetting increases in expenditure).

\footnotetext{
${ }^{8}$ In March 2011, cuts to current expenditures amounting to about 0.4 percent of GDP relative to the budget were announced as ".. a contribution to moderate inflation in a time when expectations had significantly increased" (see page 16 of the 2012 Informe de Finanzas Publicas). This measure was not included in the database given that it was clearly motivated by economic prospects. In addition, the corporate tax rate was increased from 17 percent in 2010 to 20 percent in 2011, and 18.5 percent in 2012, to help finance reconstruction linked to the February 2010 earthquake. This measure was expected to yield 0.3 percent of GDP in 2011 (see page 6 of IMF Country Report No. 12/267 and page 15 of the 2011 Informe de Finanzas Publicas). Given the nature of the motivation of the tax increase, we also chose to exclude it from the database.
} 


\section{Chile 1991}

The fiscal consolidation initiated in 1990 continued in 1991, with tax measures totaling 0.17 percent of GDP. The tax increases were motivated by the desire to maintain sound public finances. The estimated budgetary impact is net of the $2 / 3$ of new resources that were devoted to additional expenditure (i.e. 1/3 of the total 0.5 percent of GDP impact for 1991, see entry for 1990 above).

\section{Chile 2003}

Fiscal consolidation amounted to 0.6 percent of GDP, with spending cuts of 0.4 percent of GDP and tax hikes of 0.2 percent of GDP. The measures were motivated by the desire to reduce the deficit to adhere to the authorities' fiscal rule. As the 2003 Article IV staff report (SM/03/206) explains on page 14, the authorities took steps to ensure adherence to the fiscal target in 2003 and 2004. They determined that an adjustment of about 1 percent of GDP was needed to achieve the objective in 2004 reflecting, in part, declines in tariff revenue resulting from recent trade agreements. A VAT rate increase, from 18 to 19 percent, was approved by congress in October 2003.

The Informe de Finanzas Publicas accompanying the 2004 budget (published in October 2003) states on page 9 that: “... taking into account non-cyclical factors that impacted fiscal revenues in 2003, a reduction in the spending limits of several ministries and of the public treasure amounting to the equivalent of 300 million US dollars was implemented last June" This amount would be equivalent to about 0.4 percent of GDP in 2003.

The effective VAT rate (measured as VAT receipts divided by domestic demand) increased by 0.2 percentage points in 2003 to 8.3 percent and by an additional 0.5 percentage points in 2004 to 8.8 percent. This would translate into increases in revenues amounting to 0.2 percent of GDP in 2003 and 0.4 percent in 2004 in our assessment of the impact of the tax hikes.

\section{Chile 2004}

The fiscal consolidation initiated in 2003 continued in 2004, with tax measures totaling 0.4 percent of GDP in 2004. The VAT increases approved in October 2003 were motivated the desire to reduce the deficit to adhere to the authorities' fiscal rule. The estimated budgetary impact of the measures in 2004 is 0.4 of GDP as detailed in the entry for 2003 above.

\section{Chile 2008}

The level of the structural balance target was reduced from 1 percent GDP to 0.5 percent of GDP (implying a fiscal expansion of 0.5 percent of GDP). This reduction in the target was motivated by long-term considerations, namely lower fiscal risks. On motivation for this change see page 19 of the 2008 Informe de Finanzas Publicas. The report states that the structural balance target was reduced in May 2007 considering that the various fiscal risks that justified the original 1 percent of GDP target had been mitigated in recent years. 
The OECD Economic Survey report for 2007 states on page 12 that: "The level of the structural budget surplus to be targeted by the government from 2008 was reduced from 1 to 0.5 percent of GDP in May 2007. The additional funds available as a result of the reduction in the target are set to finance additional spending on education. As discussed in the 2005 Survey, this policy move is understandable against a background of an improving net asset position and the need to satisfy multiple social demands in a country of Chile's income level."

\section{Chile 2014}

A tax reform implemented gradually with a revenue impact of 0.1 percent of GDP. The reform was announced in 2014 to raise 3 percent of GDP by 2018 with 1 percent of GDP in revenues allocated to close the structural deficit and the rest to finance additional expenditure linked to the structural reform agenda (education and health). The tax reform was approved in September 2014. The 2014 article IV consultation staff report (IMF Country Report 14/218) provides a description of the reform, including the motivations behind the fiscal actions on page 10 and also in Box 2 on page 19. The reform included increases in corporate income tax rates, changes to the taxation of dividends, increases in excise duties, among other changes to the tax system.

The report indicates on page 10 that at least part of the reform aimed at reducing the deficit: "The government has proposed a major tax reform to reduce regressivity and raise 3 percent of GDP by 2018 in revenue to fund education reform, increase outlays on health, and raise public savings (see Box 2)." The selected issues paper (Rodriguez-Delgado, 2014 in IMF Country Report 14/219) further discusses the motivations for the fiscal actions and the expected impact of the reform on page 26: "The reform aims to raise 3 percent of GDP to finance an expansion in education and other social programs and to close the structural deficit (1 percent of GDP in 2014). Additional goals include improving tax progressivity, revamping incentives for savings and investment and fighting tax evasion and avoidance".

The paper presents a detailed table of the key measures with expected revenue yields as calculated by the Chilean authorities. Income tax reform would generate about 1.4 percent of GDP in additional revenues over the period. Real estate, "green", and excise taxes would yield an additional 0.9 percent of GDP, whereas tax administration and other measures would increase revenues by 0.7 percent of GDP. Implementation of the reform was planned to be gradual (see page 32 of IMF Country Report 14/219). The Corporate income tax would increase gradually staring in 2014 and yielding 0.59 percent of GDP at the "steady state". Nevertheless, changes to the PIT with an estimated net revenue yield of 0.8 percent of GDP would only come into effect in 2018. 
Furthermore, the Financial Report of the Tax Reform published by the Ministry of Finance (Informe Financiero de la Reforma Tributaria) ${ }^{9}$ presents detailed estimates of the impact of the reforms over the years as it gradually is implemented, indicating that it would yield additional revenues of 0.29 percent of GDP in 2014, 0.53 percent of GDP in 2015, 0.94 in 2016, 0.68 in 2017, and 0.73 in 2018. The 2015 Informe de Finanzas Publicas presents on page 20 an estimate of the impact of the tax reform on structural revenues in 2014 of about 0.38 percent of GDP (or close to 551.3 billion pesos).

In this context, we consider that the overall impact of the reform was 0.29 percent of GDP in 2014 , in line with authorities estimates, but only $1 / 3$ of these reform-related revenues were associated with the motivation to reduce the deficit and other long-run considerations.

Therefore, we assign an impact of around 0.1 to 2014 in the narrative database. Similarly, we assign a value of 0.18 percent of GDP for 2015 (i.e. 0.53 percent of GDP divided by three); 0.31 percent of GDP for 2016 (i.e. 0.94 percent of GDP divided by three), and 0.23 percent of GDP to 2017 (i.e. 0.68 percent of GDP divided by three).

\section{Chile 2015}

Tax reform initiated in 2014 and implemented gradually, with tax measures totaling 0.18 percent of GDP. The reform aimed to raise 3 percent of GDP by 2018 with 1 percent of GDP in revenues allocated to close the structural deficit and the rest to finance additional expenditure linked to the structural reform agenda (education and health). We assign a value of 0.18 percent of GDP for 2015 (i.e. 0.53 percent GDP divided by three) as discussed in the entry for 2014 above.

\section{Chile 2016}

Tax reform initiated in 2014 and implemented gradually, with tax measures totaling 0.31 percent of GDP. The reform aimed to raise 3 percent of GDP by 2018 with 1 percent of GDP in revenues allocated to close the structural deficit and the rest to finance additional expenditure linked to the structural reform agenda (education and health). We assign a value of 0.31 percent of GDP for 2016 (i.e. 0.94 percent GDP divided by three) as discussed in the entry for 2014 above.

\footnotetext{
${ }^{9}$ The report is available at http://www.dipres.gob.cl/594/w3-article-115572.html
} 


\section{E. Colombia ${ }^{10}$}

\section{Colombia 2000}

Fiscal consolidation consisted of capital expenditure cuts of 0.9 percent of GDP. The cuts were implemented to ensure debt sustainability in the context of an IMF-supported stabilization program. According to the 2001 Article IV staff report (EBS/01/34) on page 3: "To deal with these problems, the authorities designed a three-year stabilization program for the period through 2002 with the objective of restoring economic growth, strengthening Colombia's external position, and reducing inflation further. The program is based on exchange rate flexibility (the peso was floated in September 1999), fiscal consolidation, and a structural reform program that includes privatizations, financial sector restructuring, and a number of initiatives to strengthen efficiency and expenditure control at all levels of the public sector". Same report, on page 38 , indicates that actual cuts in capital expenditures in 2000 amounted to 0.9 percent of GDP.

The 2002 Article IV staff report (EBS/02/210) on page 9 states that: "During the discussions, the authorities underscored their commitment to take the measures needed to ensure public debt sustainability and maintain Colombia's record of servicing its debt. Accordingly, the program calls for tax reforms and expenditure cuts, supported by key structural measures and administrative improvements in the public sector".

\section{Colombia 2003}

Fiscal consolidation with a net effect estimated at 1.1 percent of GDP, based on tax hikes amounting to 1.6 percent of GDP, partly offset by higher capital expenditures (0.5 percent of GDP). A fiscal consolidation package was approved in December 2002 motivated by a need to reduce the deficit and debt levels. The 2003 first SBA review staff report (IMF Country Report 03/181) states on page 6 that: "The economic program for 2003-04 seeks to strengthen fiscal policy to ease the public debt burden and to advance structural reforms, with a view to reducing the economy's vulnerability and promoting more rapid economic

\footnotetext{
${ }^{10} \mathrm{~A}$ fiscal adjustment consisting of cuts in investment spending and increases in public tariffs was implemented by the new administration that took office in 1990, but was primarily motivated by the need to reduce inflation, as indicated on pages 2 and 4 of the 1991 Article IV staff report (SM/91/204): "The program of the authorities for 1990 envisaged a reduction in the rate of inflation to 24 percent and a moderate overall balance of payments surplus. A rate of growth of real GDP of 3 percent was expected to be consistent with these objectives". In 1991, revenue measures, including an increase in the VAT rate from 10 to 12 percent in January were also motivated by the need to reduce inflation. Page 5 of the 1991 Article IV staff report (SM/91/204) states that: "At the beginning of 1991 the authorities framed a program that aimed at reducing the 12-month rate of inflation to 22 percent by the end of the year". See the 1991 Article IV staff report (SM/91/204) page 7 and the 1992 Article IV report (SM/92/93) page 2 for a description of these measures and their impact. A tax reform package taking effect in January 1993, including an increase in the VAT rate from 12 to 14 percent, was more than offset by expenditure increases. See the 1993 Article IV staff report (SM/93/160) pages 4 and 5. A tax reform package approved in December 1995 was once again offset by expenditure increases. See the 1995 Article IV report (SM/95/319) page 5.
} 
growth." The same report describes on page 8 the tax reform approved by end- 2002 . Measures adopted included a one-time wealth tax, an income tax surcharge, and a broadening of the VAT base that would yield an expected revenue of 1.6 percent of GDP in 2003 and 1.2 percent of GDP in 2004.

However, there were delays in implementing part of the reform. The 2004 third SBA review staff report (IMF Country Report 04/199) states on page 5 that: "Total revenues rose to 31 percent of GDP, largely because of higher nontax revenues. ... However, tax revenues increased by less than expected, partly because the VAT increase approved in December 2002 was implemented later than expected". Table 4 on page 26 of the same report indicates that capital expenditures increased by 0.5 percent of GDP. The 2005 Article IV consultation staff report (SM/05/137) states on page 8 that part of the VAT increase was effectively nullified by the Constitutional court in 2003.

In addition, the full year impact of the reforms in 2004 was more than offset by expenditure increases (see Table 5 in 2006 Article IV consultation staff report EBS/06/131) and therefore is not included in the database. The full year effect of the 2002 tax reform in 2004 is estimated at less than 0.6 percent of GDP on page 39 of the 2004 medium-term fiscal framework report (Marco Fiscal de Mediano Plazo) prepared by the Colombian Ministry of Finance.

\section{Colombia 2011}

A tax reform with an estimated net yield of 0.4 percent of GDP was enacted in end2010. The reform was motivated by long run considerations and the need to ensure fiscal sustainability. The 2011 Article IV staff report states on page 4 that: "Elections took place in May and June 2010, and a new administration (of President Santos) took office in early August. The central bank governor remained in his position (as stipulated by the central bank law), and the new Minister of Finance launched initiatives that supported his predecessor's efforts to strengthen the fiscal framework (e.g., by adopting a fiscal package that included rationalizing tax incentives and submitting to congress important structural fiscal reforms)."

The 2011 Marco Fiscal de Mediano Plazo elaborated by the Ministry of Finance presents on page 23 some of the objectives of the reform efforts in 2010, which included: “... support the country's competitiveness, encourage the formalization of firms and of labor, and increase productivity, as well as others intended to ensure fiscal sustainability". Page 152 of the same report provides further context for the motivation behind the tax reform: "The main objective of the government in tax matters was the promotion of the competitiveness of firms supported by the simplification of the system and the adoption of measures to reduce wage and non-wage costs. In that sense, the draft law contemplates measures aimed at eliminating distortions in the decisions to allocated resources in real and financial markets". 
The tax reform closed loopholes in the financial transactions tax, eliminated tax credits and increased the net wealth tax. The estimated annual net yield of the revenue measures was 0.4 percent of GDP, even after taking into account the revenue losses from the reduction of import tariffs and electricity surcharges (see the 2011 Article IV consultation staff report IMF Country Report 11/224, page 6). Moreover, the fixed asset tax credit was set to be eliminated in 2012, which was expected to generate additional revenues in the order of 0.8 percent of GDP (see footnote 2 on Table $3 \mathrm{~b}$ on page 35 of the 2011 Article IV consultation staff report).

\section{Colombia 2012}

A tax reform initiated in 2011 with revenue measures totaling 0.8 percent of GDP. The reform was motivated by long run considerations and the need to ensure fiscal sustainability. The elimination of the fixed asset tax credit was expected to generate additional revenues in the order of 0.8 percent of GDP, as discussed in the entry for 2011 above.

In addition, a revenue neutral tax reform was approved in end-2012 motivated by long-run considerations. According to Box 5 on page 27 of the 2015 Article IV consultation staff report (IMF Country Report 15/142): “The 2012 reform aimed to improve progressivity and reduce the tax burden on labor which was hindering formality and competitiveness while being revenue neutral." The reform introduced a minimum personal income tax and partially replaced social security contributions with corporate profit-based taxes. The 2014 Article IV consultation staff report (IMF Country Report 14/146) also discusses on page 18 the motivations for and main features of the reform: "At end-2012, Congress approved a comprehensive tax reform to improve tax progressivity and reduce non-wage labor costs, including a reduction in payroll and corporate income taxes, simplification of the VAT structure, introduction of a new tax on corporate profits, and an increase in progressivity of individual income tax".

\section{Colombia 2015}

Fiscal consolidation consisted of expenditure cuts amounting to 0.5 of GDP. The cuts were motivated by the need to reduce the deficit to comply with the fiscal rule. According to the 2016 Article IV staff report (IMF Country Report 16/129), page 6: "The government cut expenditures early in 2015 (by about 0.5 percent of GDP) and benefited from the tax yield of the end-2014 tax reform ( 0.5 percent of GDP) to meet the structural target on the central government deficit." The expenditure cuts in early 2015 as well as the impact of the end2014 tax reform are also discussed on page 9 of the report on compliance with the fiscal rule for 2014 (Informe de Cumplimiento de la Regla Fiscal en 2014), published in June 2015 by the Colombian Ministry of Finance. The magnitudes reported there are in line with the ones presented in the 2016 Article IV report.

The tax reform approved in late 2014 and effective as of 2015 was expected to yield 1.5 percent of GDP in revenues by 2018. According to the 2015 Article IV consultation staff 
report (IMF Country Report 15/142), page 27, the reform was designed to: “... make up for the scheduled elimination of the wealth tax and financial transaction tax (FTT) and some expected decline oil revenue due in part to a dimmer outlook for production costs and prices". Measures included a gradual increase in corporate profit taxes from 9 percent to 18 percent by 2018 and the continuation of the personal wealth tax and financial transaction tax until 2018.

Therefore, it appears that the tax package was motivated by the need to compensate for lost revenue from other taxes that were being phased-out and for an expected decline in oil production and prices. In this context, given the criteria adopted to include action-based consolidation episodes in the database, we chose to remove the estimated effects of this reform and only include the effects of the expenditure cuts.

\section{Colombia 2016}

Fiscal consolidation consisted of expenditure cuts amounting to 0.7 percent of GDP. The cuts aimed to reduce the deficit to comply with the fiscal rule. The 2016 Article IV report (IMF Country Report 16/129) notes on page 16 that: "For the central government, the authorities are aiming at a 2016 headline deficit of 3.6 percent of GDP, to facilitate the adjustment and to protect market confidence and the credibility of the fiscal framework. To this effect, the authorities committed early this year to reduce spending by 0.7 percent of GDP through an expenditure freeze that affects investment, the wage bill and transfers, while protecting key social programs. They also plan to bolster revenue collection by about 0.5 percent of GDP through tax administration efforts underpinned by recent strengthening in technical and human resources at the tax authority". Expenditure cuts of 0.7 percent of GDP are also reported on page 11 of the report on compliance with the fiscal rule for 2015 (Informe de Cumplimiento de la Regla Fiscal en 2015), published in June 2016 by the Colombian Ministry of Finance. 


\section{F. Costa Rica ${ }^{11}$}

\section{Costa Rica 1990}

Fiscal consolidation consisted of revenue measures amounting to 1.5 percent of GDP. The measures were motivated by the need to reduce the deficit. The consolidation package also envisaged 2 percent of GDP in expenditure cuts, which were not implemented. The 1990 Article IV consultation staff report (EBS/91/40) states on pages 8 and 9 that: "A new Administration assumed office in mid-May 1990, and soon after introduced measures to reduce the fiscal deficit and to ease balance of payments pressures. A revenue package was announced in mid-June (with an estimated yield of 3 percent of GDP on an annual basis) which included: (i) an increase to 10 percent in minimum import duties on raw materials and on intermediate and capital goods; (ii) an 80 percent increase in the tax on banana exports; (iii) an increase in the range of 17-22 percent in the prices of basic grains sold by the CNP; and (iv) adjustments in the range of 20-32 percent in the prices of petroleum products, electricity, and telephone tariffs. In response to increases in international fuel prices, there were further increases of around 40 percent in petroleum product prices during the period August-December. Also in mid-June, the Government announced a freeze on the creation of new posts in the central administration, and established a ceiling of 50 percent on the number of vacancies that should be filled. In addition, ministries and decentralized agencies were requested to cut expenditure by 2 percentage points of GDP on an annual basis".

But the same report indicates on page 9 that the expenditure cuts were not fully implemented: "Preliminary data indicate that the combined fiscal deficit was reduced from 7 percent of GDP in the first half of 1990 to around 3 1/2 percent of GDP in the second half. The reduction was somewhat smaller than had been envisaged because of a further decline in export taxes due to the continued weakening in international coffee prices, unanticipated wage increases in October as a consequence of rulings made by the labor court earlier in the year and slippages in the implementation of the planned expenditure cuts."

The 1993 Article IV consultation staff report (EBS/93/45) sheds further light on the motivation for the adjustment program on page 2: "Since mid-1990 the Government has been

\footnotetext{
${ }^{11}$ A tax package with an estimated revenue yield of 0.3 percent of GDP was adopted in 2001 (2001 Article IV consultation report SM/01/190 pages 9 and 10), but was offset by increases in wage expenditures and therefore was excluded from the database. In addition, consolidation measures were adopted in late 2002/early 2003, but seem to have been mostly motivated by economic activity and therefore were also excluded from the database. The 2002 Article IV consultation staff report (SM/03/55) states on pages 7 and 8 that: "Anticipating further economic deterioration in 2003, the authorities began to take corrective measures at the end of 2002". These measures included the approval of a temporary revenue emergency package in December 2002. All tax increases would be in effect only for 2003 and were expected to yield about 1 percent of GDP in revenues. Moreover, a tax reform with the objective of reducing the fiscal deficit with an expected yield $2 \frac{1}{2}$ percent of GDP (see IMF country report 11/161 page 4 and Box 1 on page 9) was approved by congress in early 2012, but was voided by the Supreme Court in the same year (IMF Country Report 13/79 page 4). This reform was also excluded.
} 
implementing an economic program designed to reduce imbalances, give a greater role to market forces and increase Costa Rica's integration with the international economy".

Given the timing of the implementation of the revenue measures, we assign an impact of 1.5 percent of GDP to 1990 and another 1.5 percent of GDP to 1991. Table 4 on page 7 of the 1990 Article IV consultation staff report (EBS/91/40) indicates that actual expenditure cuts in 1990 were negligible consisting in a decline in the category "other capital and net lending" (while fixed capital formation remained constant as a share of GDP and current expenditures increased) with a net effect of 0.2 percent of GDP.

\section{Costa Rica 1991}

Fiscal consolidation consisted of revenue measures amounting to 3.1 percent of GDP, as a continuation of measures implemented in 1990 as well as new policy actions. The measures were taken with the objective of reducing the deficit as a continuation of the program that started in 1990 (see entry for 1990 above). The 1990 Article IV consultation staff report (EBS/91/40) states on page 14: "The centerpiece of the economic program is the reduction in the combined deficit of the public sector from 5.1 percent of GDP in 1990 (3.5 percent of GDP in the second half) to no more than 0.5 percent of GDP in 1991."

The same report describes on page 15 the main revenue measures and their estimated impact: "In early January 1991 the Assembly approved the broadening of the base of the sales tax to cover electricity charges and petroleum sales and a temporary increase in the rate of this tax from 10 to 13 percent, with an estimated yield in 1991 of 1.2 percent of GDP. The remainder of the package (comprising a progressive tax on pensions paid by the public sector, an increase in the level of presumptive income of professionals for tax purposes, and steps to improve tax collections), which is projected to yield 0.2 percent of GDP on an annual basis, is expected to be considered by the Assembly in the second half of 1991. In addition to the modifications of the sales tax, central government revenue in 1991 will be boosted by the full-year impact of the measures introduced in mid-1990 (the increase in the banana tax and in the minimum import duty on raw materials and intermediate and capital goods) and by the imposition of a 10 percent temporary import surcharge, estimated to yield 1.2 percent of GDP on an annual basis, but which is to remain in effect for only seven months (JanuaryJuly)".

"On the expenditure side, the increase in the Central Government's wage bill in 1991 is not to exceed 18 percent in 1991 (compared with increases averaging 26 percent in 1989-90), and to this end the Government will implement a plan to cut employment and limit wage adjustments. During 1991 central government employment, will be reduced by 2,300 (3.5 percent) as part of a scheme to reduce public sector employment by 9,000 (about 5 percent of total employment in the public sector." 
But the 1992 Article IV consultation staff report (EBS/92/5) indicates on page 7 that delays and exemptions in the implementation of the revenue measures led to a shortfall of 0.4 percent of GDP relative to initially expected yields: "Central government revenue fell short of program projections by nearly 2 percentage points of GDP because of shortfalls in the collection of the sales taxes ( 0.4 percent of GDP), reflecting a one-month delay in implementing the temporary rate increase from 10 to 13 percent and the exclusion of key items from the tax base; lower receipts from taxes on international trade $(0.7$ percent of GDP), in part because coffee export prices did not reach the minimum tax threshold during the year; and lower collections of income taxes and consumption duties ( 0.7 percent of GDP) because of the deceleration in economic activity (Table 5)".

Moreover, the same report indicates that the programmed expenditure cuts were not actually implemented: "Although expenditures relative to GDP were 0.5 percent lower than programmed, the program target on nominal outlays was exceeded because of overruns in domestic interest payments, the wage bill, pensions, and emergency outlays for flood and earthquake relief".

Given the timing of the implementation of the revenue measures, we assign an impact of 0.8 percent of GDP in 1991 to the increase in the sales tax (1.2 percent of GDP equivalent to the annual impact minus 0.4 percent of GDP linked to the implementation delays). Note that the sales tax increase was gradually reversed over the next three years (see below). We also include an increase of 0.1 percent of GDP in 1991 and 0.1 percent of GDP in 1992 linked to the rest of the revenue package implemented in mid-1991 with an estimated annual yield of 0.2 percent of GDP. Moreover, we also consider a budgetary impact of 1.5 percent of GDP linked to the revenue measures implemented in 1990 (see entry for 1990 above). Finally, we assign 0.7 percent of GDP to the temporary import surcharge in 1991 (i.e. 7/12*1.2) with a subsequent revenue loss of 0.7 is assigned to 1992, when the tax is scrapped.

\section{Costa Rica 1992}

Fiscal consolidation consisted of tax increases amounting to 0.5 percent of GDP on a net basis. The measures were taken with the objective of reducing the deficit as a continuation of the program that started in 1990 (see entry for 1990 above). The 1992 Article IV consultation staff report (EBS/92/5) presents on pages 13 and 14 estimates of the net effect of new revenue measures taking into account the elimination of temporary taxes introduced previously: "Notwithstanding the elimination of the temporary 10 percent import surcharge and the reduction of the sales tax from 13 to 12 percent (estimated to have contributed 1.1 percent of GDP) central government revenue is projected to increase by 0.5 percent of GDP through a tax package (referred to earlier) the major elements of which are: (a) the extension of the sales tax to fuel imports, construction materials, and industrial and commercial electricity purchases; (b) the reduction of about 50 percent in income tax and import duty exemptions; and (c) the introduction of fines and penalties for tax evasion. These measures are expected to yield additional revenues of about 0.6 percent of GDP over the period April- 
December 1992 (or 0.8 percent of GDP on an annual basis). In addition, consumption duties on selected items will be increased by 5-10 percent and the import duty on motor vehicles has been restructured to reduce the incidence of tax evasion (whereby cars were imported in components at much lower duty rates)."

"Central government expenditure is projected to decline from the equivalent of 18.4 percent of GDP in 1991 to 17.7 percent of GDP in 1992, notwithstanding a small increase in capital expenditure. ... the wage bill is projected to decline by 0.2 percent of GDP. The reform of the system of export subsidies ... will reduce expenditures by the equivalent of 0.3 percent of GDP, while the reform of the pension schemes and the cutback in transfers to some decentralized agencies will yield a reduction of another 0.2 percent of GDP”.

The 1990 Article IV consultation staff report (EBS/91/40) provides an estimate of the impact of the reduction in the sales tax rate and of the elimination of the import surcharge on page 17: "In 1992 the sales tax rate will be reduced by 1 percentage point ( 0.4 percent of GDP) as part of a plan to return to a rate of 10 percent by 1994 ... In addition, the elimination of the temporary import surcharge as from August 1991 will imply an annual revenue loss of 0.7 percent of GDP".

The 1993 Article IV consultation staff report (EBS/93/45) confirms on page 2 that the revenue measures were implemented: "Central government revenue exceeded program projections by 1.3 percentage points of GDP because of the larger than expected yield from the reduction of tax exemptions (which became effective in June 1992), a rise in imports and a major improvement in tax administration (Table 5). These factors more than compensated for the programmed reduction in the sales tax rate from 13 percent to 12 percent and a faster than envisaged reduction in import duties (including the elimination of the 10 percent import surcharge)."

The same report also suggests that expenditure cuts were not implemented: "Central government expenditures exceeded program limits by about 1.1 percentage points of GDP, mainly because of higher transfers for education and for social programs (which, by law, need to be adjusted in line with revenue collections) and pension payments, reflecting a sharp rise in the number of retirements in anticipation of an increase in the retirement age. The wage bill also was larger than expected in the program because of an average wage award of 10 percent (instead of the 6 percent incorporated in the program) granted in July 1992".

\section{Costa Rica 1993}

Reduction of sales taxes with an estimated impact 0.5 percent of GDP, partly offset by full year impact of the 1992 tax package (0.2 percent of GDP). The sales taxes were increased temporarily as part of the 1991 revenue package (see entry for 1991 above). The 1993 Article IV consultation staff report (EBS/93/45) states on pages 5 and 6 that: "The central government deficit is projected to remain virtually unchanged, in terms of GDP, in 
1993. The reduction of the sales tax from 12 percent to 11 percent with effect from January 1993 and cuts in the banana export tax (because of lower international prices) are estimated to produce a revenue loss of about 0.6 percentage points of GDP in 1993. This loss will, however, be partly offset by the full-year impact of the 1992 tax package and an increase in consumption duties on selected items (whether imported or domestically produced)". As noted in the previous section, the full year effect of the 1992 tax package in 1993 would amount to 0.2 percent of GDP.

Page 7 of the same report describes the expected impact of a number of revenue and expenditure measures that were envisaged for 1993. Nevertheless, the 1994 Article IV consultation (SM/94/273) staff report indicates on page 2 that these measures were not implemented: "However, after being in balance in the first semester, the fiscal position shifted to a deficit of 1 percent of GDP for the year as a whole as central government expenditures on wages and salaries and transfers to the private sector rose considerably while revenue remained unchanged relative to GDP (Tables 2 and 3)."

\section{Costa Rica 1994}

A reduction of sales taxes, which were increased temporarily as part of the 1991 package, with an estimated impact 0.5 percent of GDP. The sales taxes were increased temporarily as part of the 1991 revenue package (see entry for 1991 above). The 1994 Article IV consultation staff report (SM/94/273) states on page 2 that: "The sales tax rate was reduced gradually from 13 percent in 1991 to 10 percent in January 1994, resulting in a total revenue loss of some 1.5 percent of GDP by end-1994". Given the estimated revenue loss of 1.5 percent of GDP over three years, we assign a value of 0.5 percent of GDP to calendar year 1994.

\section{Costa Rica 1995}

Fiscal consolidation amounted to 1.8 percent of GDP with tax hikes of 1 percent of GDP and expenditure cuts of 0.8 percent of GDP. The measures were taken with the objective of reducing the deficit and for long-run considerations. The 1995 SBA request report (EBS/95/169) states the objectives of the program on page 4: "The economic program for 1995-96 aims at establishing the basis for sustained economic growth by increasing domestic savings; improving efficiency in the public sector through restructuring and reducing rigidities in expenditure; increasing the role of the private sector; and enhancing competition, efficiency, and soundness in the financial system".

The same report indicates on page 3 that: "Despite the downturn in economic activity, the public finances improved in the first half of 1995, with the overall deficit narrowing to 4 percent of GDP on an annual basis. The improvement resulted from tight controls over expenditure, the introduction of a temporary import surcharge, and increases in consumption taxes. Also, water and electricity tariffs were adjusted, and the fuel surcharge for electricity was almost doubled. ... Confidence in the economy improved in the third quarter of 1995, 
and concerns of an immediate risk of a banking crisis receded, following an agreement reached in June between the Government and the main opposition party on a program of economic reforms, and the approval of measures (including the tax package and pension reform) to strengthen the public finances".

Details of revenue package are presented on pages 4 and 5 of the report: "Tax revenue would increase from 14 percent of GDP in 1994 to 17 percent in 1996, reflecting mainly an increase in the sales tax rate from 10 percent to 15 percent, which would yield about 2 percentage points of GDP. Other additional revenues would stem from a new export tax structure for coffee which captures part of the windfall from higher coffee prices, increases in consumption taxes, a 1 percent tax on gross assets of corporations, a consumption tax on petroleum products, and the unification of the tax rate on company profits. Noninterest current expenditure (including non-recurrent severance payments) of the Central Government would be reduced by 1 percentage point of GDP to 12.2 percent in 1996 , by containing outlays on wages and transfers which accounted for 90 percent of the total in 1994".

But the 1996 Article IV consultation staff report (EBS/96/82) points to delays in adopting the tax measures in 1995, in particular for the 5 percentage point increase in the sales tax from 10 to 15 percent. ${ }^{12}$ Page 4 of the report states that: "The overall deficit of the Central Government narrowed from 5.0 percent of GDP in 1994 to 4.4 percent in 1995 (4.1 percent in the program), reflecting a shortfall in tax revenue of 1 percentage point of GDP due mainly to the delayed implementation of tax measures and lower imports, which was offset in part by reducing current transfers (Table 4)". Pages 44-45 of the same report provide additional details on expenditure cuts: "The shortfall in 1995 is explained by lower tax revenues of 1 percent of GDP-- stemming mainly from delays in the implementation of tax measures and lower imports- -which was partially offset by a cut in expenditures of 0.8 percent of GDP”.

Taking these observations into account, due to delays in implementation, we assign an increase in revenues of 1 percent of GDP in 1995 to the effects of the tax reform, rather than the initially expected yield of 2 percent of GDP. The full year impact of the reform in 1996 was partly offset by increases in current primary expenditures amounting to 0.7 percent of GDP, while capital expenditures remained constant a share of GDP (IMF Country Report 98/45, page 10 and Table 16 on page 63). Therefore, we assign a revenue yield of 0.3 percent of GDP to the reform in 1996. In addition, we consider the effective expenditure cuts of 0.8 percent of GDP in 1995 highlighted in the 1996 Article IV report (EBS/96/82).

${ }^{12}$ A new tax code was approved in September 1995 (IMF Country Report 98/45, page 19). 


\section{Costa Rica 1996}

The fiscal consolidation initiated in 1995 continued in 1996, with tax measures totaling 0.3 percent of GDP. The measures were motivated by the need to maintain sound public finances (see entry for 1995 above). The full year impact of the reform initiated in 1995 was partly offset by increases in current primary expenditures in 1996 amounting to 0.7 percent of GDP, while capital expenditures remained constant a share of GDP (IMF Country Report 98/45, page 10 and Table 16 on page 63 ).

\section{Costa Rica 1997}

Fiscal consolidation consisted of expenditure cuts of 0.4 percent of GDP. The measures were motivated by a need to reduce the deficit. The Recent Economic Developments report for 1998 (IMF Country Report 98/45) discusses on page 10 the motivations and measures adopted by authorities. The report notes that: "Concerned about the rapidly rising fiscal deficit ..., the authorities announced in December 1996 an ambitious fiscal package ... . In early 1997, the authorities moved swiftly to implement fiscal measures that did not require approval by the assembly." Revenue measures included an increase in the consumption tax for gasoline with an expected yield of 0.6 percent of GDP, tax administration measures with an expected yield of 0.2 percent of GDP, and an increase in excise taxes on luxury cars with an expected yield of 0.1 percent of GDP. The authorities also decided to delay a reduction of import duties on consumption and intermediate goods to 1998 (with an estimated impact of 0.1 percent of GDP). On the expenditure-side, cuts included reductions in investment spending amounting to 0.4 percent of GDP.

These measures were partly offset by the unwinding of the temporary increase in the sales tax rate. As noted in the 1995 SBA request report (EBS/95/169) footnote 1: "The increase in the rate was approved for 18 months. In March 1997, the rate will be reduced to 13 percent, with sales tax collections being adversely affected by about 1 percent of GDP on an annual basis". In this context, we assign a no net impact of revenue measures ( 1 percent of GDP linked to the new measures minus 1 percent of GDP linked to the decrease in the sales tax rate), which together with the expenditure cuts would bring the overall size of the consolidation package to 0.4 percent of GDP.

\section{Costa Rica 2016}

Fiscal consolidation package amounted to 0.4 percent of GDP, with tax hikes of 0.2 percent of GDP and expenditure cuts of 0.2 percent of GDP. The measures were motivated by the need to reduce debt. The 2016 Article IV consultation report (IMF Country Report 16/131) sheds light on the motivation for the adjustment in the executive summary: "The authorities appropriately intend to begin gradual fiscal adjustment in 2016 to reduce the sustainability gap, though most of the measures require approval by the opposition-controlled Congress". Page 15 of the same report also states that: "Indeed, the authorities are pursuing a sizable reduction in the deficit in 2016 as part of a gradual path toward fiscal sustainability". The details of the fiscal consolidation measures are presented on pages 17 and 19 of the 
report. The fiscal package includes reforms to the VAT and incomes taxes as well as anti-tax evasion measures with an expected overall yield of 0.4 percent of GDP for 2016. Expenditure cuts would amount to 0.4 percent of GDP in 2016 and are centered around the reduction of transfers to decentralized entities and other cuts to current expenditures. The details of the proposed reforms are also presented on page 21 of the OECD 2016 Economic Survey report for Costa Rica.

Nevertheless, the government was not able to obtain support in Congress to pass the VAT and income tax reform. As a result, most of the consolidation efforts focused on the containment in the wage bill growth and efforts to combat tax evasion. As discussed in the 2017 Article IV consultation report (IMF Country Report 17/156) page 9: "The fiscal deficit remains high and public debt continues to rise rapidly despite the authorities' deepened consolidation efforts in 2016. Having maintained a broadly unchanged non-interest balance in the first two years of the administration, the government's determination to contain wage bill growth and lower personal income tax evasion allowed a reduction in the primary deficit of about $1 / 2$ percent of GDP to $2 \frac{1}{2}$ percent of GDP last year, imparting an equivalent negative fiscal impulse".

The estimates presented on page 19 of the 2016 Article IV consultation report (IMF Country Report 16/131) suggest that the anti-evasion measures would yield a budgetary impact of 0.2 percent of GDP. Table 6 on page 41 of the 2017 Article IV consultation report (IMF Country Report 17/156) indicates that compensation of employees for the consolidated public sector fell by 0.2 percent of GDP in 2016. 


\section{G. Dominican Republic ${ }^{13}$}

\section{Dominican Republic 2004}

Fiscal consolidation of 1.7 percent of GDP, with about 0.5 percent of GDP in tax hikes and 1.2 percent of GDP in spending cuts. The measures were motivated by the need to reduce debt rand by long-run considerations. The 2005 Article IV staff report (EBS/05/140) presents in the executive summary (page 4) the motivation for the adjustment measures: "The financial crisis of 2003 led to a severe recession combined with a significant rise in public indebtedness, and two attempts to implement a Fund-supported program in late 2003 and early 2004 were unsuccessful. Upon taking office in August 2004, the new government formulated a comprehensive and ambitious program aimed at addressing the weaknesses in macroeconomic policies and in a wide range of structural areas". The motivation for the

\footnotetext{
${ }^{13}$ Starting in August 1990, the government embarked on an economic reform program (entitled "New Economic Program") and adopted fiscal consolidation measures to increase tax revenues and cut capital expenditures that led to a reduction in the public sector deficit of more than 1 percentage point of GDP in 1990. In addition, an extension of the base for the 15 percent special surcharge on imports announced in July 1991 was expected to provide revenues equivalent to $1 \frac{1}{2}$ percent of GDP and an increase in administered fuel prices would generate revenues in the order of $1 / 2$ percent of GDP during that year (page 9 of the 1991 Article IV staff report-EBS/91/127). On the expenditure side, Table 3 on page 18 of the 1992 Article IV consultation staff report (EBS/92/168) indicates that actual cuts the order of 0.4 percent of GDP for capital expenditures and an additional 0.4 percent of GDP for current expenditures in 1991, which were more modest than what was announced in the program ( 2 percent of GDP). A tax reform that among other measures would broaden the VAT base and increase rates by 2 percentage points to 8 percent was enacted in the first half of 1992 and was expected to generate revenues in the order of 1 percent of GDP (EBS/91/127 page 9 and 1992 Article IV consultation staff report EBS/92/168 page 5). Nevertheless, all these measures were motivated by concerns over inflation, as evidenced by the description of the program objectives on page 8 of the 1991 Article IV staff report (EBS/91/127): "The economic program which the authorities have been carrying out since mid-1990 has sought to improve the balance of payments performance, reduce inflation and create the conditions for sustained economic growth, while protecting the poorer segments of the population". Therefore, the measures were not included in the database. Moreover, as discussed on page 2 of the 1996 Article IV staff report (SM/96/102), the authorities adopted tax measures in 1995 that were offset by the impact of the wage increases (granted in May 1995) as well as declines in revenue from international trade and from the failure to pass-through changes in international oil prices to domestic prices at the pump. A tax reform was implemented in late 2000/early 2001 with an estimated impact of 1.5 percent of GDP. The 2000 Article IV consultation staff report (SM/01/41) sheds light on the motivation for the policy actions for the 2001 program on page 15: "The authorities saw a tightening of fiscal policy as key to restraining the growth of domestic demand, and they noted several revenue and expenditure measures that have already been, or soon would be, taken (Box 1)". The 2002 Article IV consultation staff report (SM/02/148) presents an estimate of net effect of measures on page 6 . We consider that this episode was motivated by prospective economic conditions and exclude it from the database. The large improvement in the fiscal balance observed in 2015 seems to be mostly related to a capital grant from the restructuring of the Petrocaribe debt (see page 7 of the 2015 Article IV consultation staff report IMF Country Report No. 16/342. The 2017 Article IV consultation staff report (IMF Country Report No. 17/254) explains further in footnote 3 on page 6 that: "The gains from the 2015 restructuring of the country's debt under the PetroCaribe arrangement with Venezuela, bought back at a discount of over 50 percent, are recorded as an above-the-line capital grant in 2015 ( 3 percent of GDP), boosting the headline fiscal balance for that year." See also page 16 of the 2016 Informe Explicativo y Politica Presupostaria report.
} 
program is further discussed in the 2009 Article IV staff report (IMF Country Report No. 10/135) on page 26: "A process of fiscal consolidation began after the 2003 crisis, aimed at reducing the consolidated public debt-to-GDP ratio from close to 60 percent of GDP to its pre-crisis level of 25 percent of GDP". ${ }^{14}$

Tax measures with an expected revenue yield of 0.5 of percent of GDP were approved by Congress in January (see the Letter of Intent for the 1st SBA review report EBS/04/8). These included increases in excise tax rates on alcohol, tobacco and other products and the elimination of income tax exemptions for interest accruing to corporations on central bank certificates and on the income of savings and loan associations.

On the expenditure side, the report for the $3^{\text {rd }}$ and $4^{\text {th }}$ reviews of the Stand-by arrangement in 2006 (EBS/06/62) shows in Table 7 on page 41 that primary expenditure fell with 1.2 percent of GDP in 2004. This is somewhat short of authorities' original plan of expenditure cuts of 2 percent of GDP, stated in the Letter of Intent accompanying the report for the $1^{\text {st }}$ SBA review (EBS/04/8).

\section{Dominican Republic 2006}

A tax reform entailing a decline in revenues of 0.8 percent of GDP in 2006 on a net basis. The reform was motivated by long-run considerations and was approved in early December 2005. It aimed to partly offset anticipated revenue losses stemming from the effect of the ratification of a free trade agreement DR-CAFTA (0.3 percent of GDP); as well as the elimination of the foreign exchange commission (2.7 percent of GDP); and the removal of the financial transaction tax ( 0.2 percent of GDP). The report for the $3^{\text {rd }}$ and $4^{\text {th }}$ review of the Stand-by arrangement in 2006 (EBS/06/62) presents detailed estimates of the measures on Page 8 and Box 1.

The (partly) compensating measures adopted in the tax reform included the elimination of some VAT exemptions (with an estimated yield of 0.4 percent in 2006); new and higher excises taxes (with an estimated yield of 1.3 percent of GDP); a temporary increase in the corporate and personal income tax rate (with estimated yield of 0.8 percent of GDP). Nevertheless, these would not fully offset the expected revenue losses. The report indicates that the total revenue shortfall in 2006 would be about 0.8 percent of GDP.

\section{Dominican Republic 2007}

Fiscal consolidation consisted of tax hikes with an estimated impact of 0.9 percent of GDP. The measures aimed at improving the primary balance in the context of an IMF supported program. The report for the $5^{\text {th }}$ and $6^{\text {th }}$ SBA reviews (EBS/07/12) discusses on page 4 the motivation behind the adjustment measures after deviations from program targets

\footnotetext{
${ }^{14}$ Note that the Ministry of Finance has revised the methodology to calculate public sector debt. Under the new methodology, the debt to GDP ratio in 2004 would amount to 46.9 percent of GDP.
} 
in 2006: "Measures have been implemented to bring the fiscal program back on track in 2007 , with a consolidated public sector primary surplus of 2.3 percent of GDP (an overall NFPS surplus of 0.5 percent of GDP)". Pages 6 and 7 of the same report present details of the tax measures that were expected to yield 1.5 percent of GDP in additional revenue: "On the revenue side, a tax package, projected to yield about 1.5 percent of GDP, focuses on rationalizing excises to reduce distortions and increase rates on alcohol, cigarettes, and some fuels, and including excises in the VAT base, in line with best international practices. The package also contains important tax administration measures, including increased penalties for non-compliance". Congressional approval of the tax package was a prior action for the completion of the $5^{\text {th }}$ and $6^{\text {th }}$ reviews of the program (see the Table 3 on page 21 of the report) and occurred in end-2006.

Nonetheless, in June 2007 the President submitted to congress tax measures that reduced excise and income tax rates and established a limited tax amnesty (the $7^{\text {th }}$ SBA review report EBS/07/79 pages 5 and 6). Excise rates were partly scaled-back after the end-2006 increase, but were still significantly above previous levels. The report states that: "The authorities were of the view that the increase in excise rates on tobacco and spirits approved by congress last year have induced a significant rise in evasion and contraband and a large reduction in consumption". As far as the reduction in income tax rates is concerned, the report indicates that it was not expected to have a significant impact on revenues in 2007.

We adjust the total revenue yield of the tax reform by using an estimate the net revenue effect of these changes to excise tax rates based on changes in IMF staff's projections for revenues from these specific taxes for 2007. Table $6 \mathrm{~b}$ on page 25 of the report for the $5^{\text {th }}$ and $6^{\text {th }}$ SBA reviews (EBS/07/12) presents the revenue forecasts as of February 2007 incorporating the impact of the end-2006 tax measures. It indicates that excise tax revenue would increase by 0.9 percent of GDP in 2007 . Table $4 \mathrm{~b}$ on page 21 of the $7^{\text {th }}$ SBA review report (EBS/07/79) suggests a milder increase of 0.3 percent of GDP, implying a difference of 0.6 percent of GDP, which we attribute to the June 2007 tax package. Therefore, we adjust the initially estimated tax yield of the reform (1.5 percent of GDP), by 0.6 percent of GDP and consider that the overall revenue yield of the tax measures in 2007 would amount to 0.9 percent of GDP.

The report for the $5^{\text {th }}$ and $6^{\text {th }}$ SBA reviews (EBS/07/12) also mentions the authorities' intentions to cut public expenditure by about 1 percent of GDP. Nevertheless, these were not implemented and primary expenditure remained broadly constant as a share of GDP (see Table 3 on page 16 of the 2008 First Post-Program Monitoring Review EBS/08/161).

\section{Dominican Republic 2011}

Fiscal consolidation amounted to 0.64 percent of GDP, with tax measures of 0.44 percent of GDP and expenditure cuts of 0.2 percent of GDP. The measures were motivated by the need to reduce debt. The 2009 Article IV staff report (IMF Country Report 
No. 10/135) contains a description of the objectives of the authorities' program for 2009-12 on page 24: "The program's objectives are to pursue a countercyclical policy at the beginning of the program and then to switch focus to sustainability and structural issues in the remaining period of the program as laid out during the surveillance discussions". Footnote 2 of the same report indicates that sustainability issues will be the main policy concern in the remaining 70 percent of the program time (starting in the third quarter of 2010).

The Letter of Intent on page 59 of the $20112^{\text {nd }}$ and $3^{\text {rd }}$ SBA reviews (IMF Country Report No. 11/71) further illustrates the motivation for the fiscal measures: "A principal objective under the program is to implement a gradual fiscal consolidation to safeguard public debt sustainability and to reduce the debt to GDP ratio to the level observed before the international financial crisis (about 35 percent in 2007-08) by 2014 and regain fiscal space after the expansionary phase of the program that ended in mid-2010, while at the same time trying to increase public investment as much as possible through efficiency gains in revenues and expenditures".

The report for the $5^{\text {th }}$ and $6^{\text {th }}$ reviews of the SBA (EBS/11/113) discusses on pages 15,17 and 19 the package of tax measures proposed by authorities that was approved by Congress in late June 2011 through an omnibus law including all legal changes needed and several decrees. Estimates presented on page 21 of the report indicate that tax measures would yield 0.44 percent of GDP in additional revenues in 2011. Tax policy changes included the introduction of a tax on banks' financial assets (yielding about 0.1 percent of GDP), taxation on free trade zones (generating about 0.03 percent of GDP in revenues), and an increase in presumptive income taxation on gambling ( 0.1 percent of GDP in additional revenues).

The $2^{\text {nd }}$ and $3^{\text {rd }}$ SBA reviews (IMF Country Report No. 11/71) discusses on page 23 the measures to be adopted on the expenditure side to help achieve an overall fiscal consolidation of 1 percent of GDP in 2011. Authorities intended to reduce transfers to the electricity sector to 0.6 percent of GDP and cut expenditure on goods and services by 0.2 percent of GDP. But Table 2 on page 24 of the 2012 Article IV consultation staff report (EBS/12/176) suggests that overall primary expenditures declined only by 0.2 percent of GDP in 2011 .

\section{Dominican Republic 2013}

Fiscal consolidation amounted to 3.8 percent of GDP, with a tax package of about 1.8 percent of GDP and expenditure cuts of 2 percent of GDP. The measures were motivated by the need to reduce the deficit and for long run considerations. In November 2012, the new government secured congressional approval for a tax reform with an estimated annual yield of 1.8 percent of GDP as described on page 9 and Box 3 of the 2012 Article IV consultation staff report (EBS/12/176). The tax reform comprised an increase in the VAT rate from 16 to 18 percent among other measures. The 2013 Informe Explicativo y Politica Presupostaria report elaborated by the Ministry of Finance sheds light on the motivation for the reform on page 10: "This law's objective is to collect additional revenues through the increase of some 
tax rates, the rationalization of tax expenditures, and the implementation of measures to improve efficiency, transparency and equity of the tax system".

On the expenditure side, the authorities envisaged cuts to existing programs that were expected to generate savings of up to 4 percent of GDP in 2013, but the effects of these measures would be partly offset by new initiatives with a projected cost of about 2 percent of GDP, according to Box 3 in the 2012 Article IV consultation staff report (EBS/12/176). The motivation for the expenditure cuts is presented in the discussion of expenditure policy on page 14 of the 2013 Informe Explicativo y Politica Presupostaria report, which states that: "The government in its firm commitment to fiscal sustainability proposes a reduction in the fiscal deficit to 2.8 percent of GDP ...". Table 2 on page 29 of the 2015 Article IV consultation staff report (IMF Country Report No. 16/342) confirms that primary current expenditures increased by about 0.5 percent of GDP in 2013, whereas capital expenditures fell by 2.6 percent of GDP. 


\section{H. Ecuador ${ }^{15}$}

\section{Ecuador 1990}

Fiscal consolidation consisted of revenue measures with an estimated net impact of 0.33 percent of GDP. The 1990 SBA review report (EBS/90/43) sheds light on the motivations for the fiscal adjustment on page 11: “The authorities' program for 1990 aims to achieve a further reduction in external and internal imbalances so as to improve the medium-term prospects for sustained economic growth and external viability."

${ }^{15}$ In 1989 the government adopted several revenue measures in the context of an SBA-supported program (see 1989 Article IV consultation staff report EBS 89/164, page 11). We did not include this episode in the database because the measures seem to have been motivated by a desire to stabilize the economy. The letter of intent for the 1989 SBA request (EBS/89/161) states on page 1 that: "Twenty days after having assumed office, on August 30, 1988, the Ecuadoran Government, in use of its sovereign faculties, adopted an emergency economic program based on a new economic approach consistent with its political philosophy, which was aimed at stabilizing the economy as a first step toward its subsequent recovery ...". See also Page 44 of the 1989 Article IV consultation staff report (EBS 89/164).

Several fiscal actions were undertaken in 1994 as a response to a decline in international oil prices (especially the tax reform passed in December 1993 and expenditure cuts), as discussed in the 1994 Article IV consultation staff report (EBS/94/88) page 4. This episode was also excluded from the database.

Moreover, a number of policy actions were also implemented in 1997. Nevertheless, we decided not to include them in the database as they seem to have been motivated by a desire by authorities to stabilize the economy, as indicated in the 1997 Article IV consultation staff report (SM/97/212) page 14.

A revenue package consisting of an increase in an import surcharge and a financial transactions tax was implemented starting in February 1999 with an estimated impact of 1.3 percent GDP. But the measures were motivated by a fall in oil prices in 1998 and lack of external financing, hence we chose to exclude this episode from the database (see section IV for a more detailed description of this episode).

A tax reform was adopted in 2001, but the measures were subsequently reversed and therefore not included in the database. Gunter et al. (2017) flag the increase in the VAT rate by 2 percentage points associated with the tax reform as exogenous with a debt-driven motivation. Nevertheless, the VAT rate increase was reversed subsequently. According to the 2001 2nd SBA review staff report (EBS/01/72), the expected net increase in fiscal revenues deriving from policy measures in 2001 would be around $1 / 2$ percent of GDP (Box 2 on page 15). Nevertheless, the 3rd and 4th SBA review staff report (EBS/01/200) states on page 12 that: "In particular, preliminary data on VAT payments through September indicate that improved collection efficiency will almost fully offset the estimated revenue loss (about US\$70 million) following the August 2001 reversal by the constitutional tribunal of the increase in the VAT rate (bringing it back to 12 percent from 14 percent) that had been part of the 2001 fiscal program."

Moreover, a tax reform with the objective of improving equity and raising the tax to GDP ratio was approved by the constituent assembly in December 2007 with an expected yield of 0.6 percent of GDP (2007 Article IV consultation staff report SM/08/11, page 15), but was its impact was more than offset by increases in expenditure.

In addition, a large fiscal adjustment took place in 2015 with tax measures expected to yield revenue increases in the order of 2.5 percent of GDP, whereas expenditure cuts would amount to close to 3 percent of GDP. But the 2015 Article IV staff report (IMF Country Report 15/289) indicates on page 5 that the adjustment was a response to a sharp decline in oil prices and other external shocks. Page 9 and Box 2 on page 21 of the report present details the measures and their estimated impacts. Given the motivations for the adjustment described above, we chose to exclude this episode from the database. 
Estimates of the budgetary impact of the revenue measures are presented on page 12 of the same report. It was expected that the authorities' decision to implement a policy of monthly increases in domestic prices of petroleum products would lead to additional revenues of 1.1 percent of GDP. Nevertheless, a decline in revenues of about 0.5 percent of GDP stemming from the introduction of a reform of income and indirect taxes (effective as of January 1, 1990) and of import tariff rates was also expected. This reform intended to render the tax system more efficient and equitable (see page 14 of the report for a description of the tax reform and page 42 for a discussion of the objectives for the reform). Moreover, the policy of monthly adjustments of domestic petroleum products was halted in September 1990 because of Congressional opposition (see the 1991 SBA request report, EBS/91/192, page 5).

Given this information, we assign a budgetary impact for the measures amounting to 0.33 percent of GDP in 1990. This corresponds to 0.83 percent of GDP, which is given by $3 / 4$ of the estimated annual impact of the monthly adjustments in petroleum product prices that was halted after September (i.e. $0.75 * 1.1$ percent of GDP) minus the revenue losses of associated with the tax reform ( 0.5 percent of GDP).

\section{Ecuador 1993}

Fiscal consolidation amounted to 2.2 percent of GDP, with revenue measures of 1.7 percent of GDP and expenditure cuts of 0.5 percent of GDP (mostly to capital

expenditure). The measures were motivated by the need to reduce the deficit. The 1992 Article IV Staff report (SM/92/220) states on page 3 that: "President Duran-Ballen was elected in July 1992 for a four-year term on a platform that stressed the need for economic adjustment, reliance on market forces, and structural reforms to scale down the public sector, deregulate the economy, and improve resource allocation. The Administration took office on August 10 and in early September announced measures in the fiscal, monetary, and foreign exchange areas". Fiscal measures were expected to yield savings of about 6 percent of GDP on an annual basis and included adjustments in fuel prices, in electricity tariffs, and a onetime levy in the range of 0.2-0.7 percent on company assets.

The 1994 Article IV staff report (EBS/94/88) states on page 2 that: "The combined public sector deficit was reduced from 3.9 percent of GDP in 1992 to 0.4 percent of GDP in 1993, as a drop in oil export revenue related to lower world prices was more than offset by the fullyear effect of the public tariff adjustments in September 1992 and a reduction in public spending (Table 3 and Statistical Appendix Table 9)." Table 3 in the report shows that revenues from domestic petroleum product sales increased from 1.7 percent of GDP in 1992 to 3.4 percent of GDP in 1993, while real GDP growth decelerated from 3.5 percent in 1992 to 1.7 percent in 1993. In that context, it is likely that the bulk of the observed increase in revenues from domestic petroleum product sales was due to the tariff increase. On the expenditure side, current primary spending fell by 0.1 percentage point of GDP relative to 1992, while capital expenditures fell by 0.4 percentage points of GDP ( 0.7 percentage points relative to the program target). 


\section{Ecuador 2000}

Fiscal consolidation amounted to 0.5 percent of GDP, with revenue measures of 1.3 percent of GDP that were partly offset by expenditure increases of 0.8 percent of GDP. The objective of the revenue measures was ensuring medium-term fiscal sustainability. The economic context was a move to a fully dollarized exchange rate regime and an IMF supported program. As discussed on page 15 of the 2000 SBA request report (EBS/00/66): "On assuming office, and in light of the more stable financial conditions that had prevailed since the dollarization announcement, President Noboa decided to continue with the strategy using it as a means to enforce greater fiscal discipline and to enact legislation aimed at strengthening the banking sector." Furthermore, page 19 of the same report states that: "The fiscal program aims at adapting the fiscal position to the realities of a dollarized regime and at setting the basis for moving toward medium-term viability. It also seeks to ensure that the programmed fiscal deficit can be financed after incorporating feasible exceptional financing, while avoiding, to the extent possible, major fiscal contraction in an economy where demand has already collapsed."

Additional information on the motivation for the program is presented in the Executive Summary on page 4 of the 2000 Article IV Consultation Staff report (EBS/00/164): "The economic program aims to restore confidence in economic management, stem the decline in economic activity, and lay the basis for economic recovery through: the dollarization of the economy; a substantial reduction in the combined fiscal deficit, consistent with a further improvement in the primary balance; significant structural reforms aimed at addressing the weaknesses in Ecuador's financial system, achieving a more flexible labor market, and facilitating the privatization of major state enterprises; and private sector involvement to secure additional external financing from debt relief and reduction."

In this context, we consider that the fiscal measures were not a response to a worsening in current or prospective economic conditions. The measures seem to have been primarily motivated by prudential considerations. The 2000 SBA request report (EBS/00/66) report indicates on page 19 that the main measures to improve the fiscal balance involved a significant increase in domestic prices for petroleum products (reduction of subsidies) and tight control over expenditures, including on the wage bill. The adjustment in domestic fuel prices was expected to yield 1.3 percent of GDP in additional revenue in 2000. Page 21 of the report also discusses cuts in current expenditures that would amount to 2 percent of GDP, mainly concentrated on cuts to the wage bill. Capital expenditure would increase by one percent of GDP under the program. But it appears that capital expenditures were underexecuted (they fell as a share of GDP), whereas the decline on the wage bill was more than offset by increases elsewhere. Overall, Table 2 on page 28 of the 2003 Article IV consultation staff report shows that primary expenditures for the non-financial public sector increased by 0.8 percent of GDP. 


\section{Guatemala ${ }^{16}$}

\section{Guatemala 1995}

Fiscal consolidation consisted of tax hikes of 0.8 percent of GDP. The measures were motivated by the need to reduce the deficit. The tax package included: (i) a new minimum tax of $1 \frac{1}{2}$ percent on gross assets; (ii) an increase in the corporate income tax and in the top rate for the personal income tax from 25 to 30 percent; (iii) the elimination of certain VAT exemptions; (iv) and an increase in the VAT rate from 7 to 10 percent effective as of January 1996 (see the 1998 Recent Economic Developments report SM/98/95 Supplement 1 for a description of the measures). But, the implementation of some elements of the package (including the tax on gross assets) was suspended because of challenges by the Constitutional Court in April 1995. According to the 1995 Article IV staff report (SM/95/93), the original set of measures would have a revenue yield of 1.1 percent of GDP. Subsequently, Congress approved legislation that would in part compensate for some of the revenue loss from the legal challenge, but a shortfall of 0.3 percent of GDP would remain.

The 1995 Article IV staff report (SM/95/93) explains the motivations for the tax measures on page 4: "The authorities have stressed that their overriding near-term objective is to achieve a significant reduction of the combined public sector deficit during 1995, and that they would work on building political support for further actions to compensate fully for the effect of the Court's decision on government revenues".

The 1996 Article IV consultation staff report (SM/96/247) also sheds light on the motivations for the policy actions on page 2: "In 1995 the outgoing administration of President De Leon Carpio adopted an economic program that was monitored by the staff on an informal basis. The program envisaged a reduction in the combined public sector deficit to 1.3 percent of GDP in 1995, to be supported by a restrained credit policy".

\footnotetext{
${ }^{16}$ In 1991 authorities adopted temporary measures to increase revenue, including a tax amnesty and a one-time 2 percent tax on exports with an estimated impact of 1 percent of GDP. Nevertheless, these actions were motivated by economic conditions as described in the Memorandum on Economic and Financial Policies (MEFP) on page 35 of the 1992 Article IV consultation staff report (EBS/92/187): "The Administration of President Serrano, upon assuming office in January 1991, was confronted with a severe economic crisis resulting from persistent large fiscal deficits, poor management of exchange rate policy, and negative real interest rates which led to a decline in domestic savings and encouraged capital flight. ... Against this background, the new Administration initiated a stabilization program aimed at reducing inflation and improving the external position".

Moreover, A tax reform was implemented in July 1992 with an estimated revenue yield of 1.3 percent of GDP in 1993, motivated by the desire to reduce the deficit (see pages 3 and 4 of the 1992 Article IV consultation staff report EBS/92/187), but the impact of the reform was more than offset by increases in expenditures (especially wages), as discussed in the 1993 Article IV consultation staff report SM/94/50.
} 


\section{Guatemala 1996}

Fiscal consolidation consisted of revenue measures of 0.7 percent of GDP. In terms of motivation, they were essentially a continuation of the policies adopted in 1995. Their net revenue yields are discussed on page 6 of the 1996 Article IV consultation staff report (SM/96/247). They included an increase in the VAT rate in January from 7 to 10 percent and the introduction in mid-1996 of a temporary tax of one percent on the gross income of individuals and corporations (ISET) that would more than offset a projected decline in revenue from import duties due to the lower common external tariff.

Going forward, the new administration that took office in January 1996 aimed to substantially increase social spending and investment outlays, financed by raising tax revenue by about 4 percentage points of GDP over the period 1996-2000 (see page 5 of the 1996 Article IV consultation staff report). Nevertheless, the administration opted to first conclude the peace negotiations before proposing any new revenue measures.

\section{Guatemala 2000}

Fiscal consolidation amounted to 1.3 percent of GDP with expenditure cuts of 1 percent of GDP and tax measures of 0.3 percent of GDP. The measures were motivated by the need to reduce an inherited deficit. According to page 7 of the 2001 Article IV consultation staff report (SM/O1/116), capital expenditure cuts amounting to 1.5 percent of GDP were implemented in 2000. Nevertheless, current expenditures rose by 0.5 percent of GDP because of an across-the-board wage increase of 9 percent, a 3 percent increase in the size of the civil service workforce, and higher spending on goods and services. The new administration also introduced a tax package in June 2000, which contributed to improve tax revenues by an estimated 0.3 percent of GDP. Measures included: (i) an increase in the top income tax rate; and (ii) a widening the VAT base to include custom duties and phase out some exemptions.

The 2001 Recent Economic Developments report (SM /01/139) sheds light on the motivations for the policy actions on page 12: "Since taking office in January 2000, the administration of President Portillo has sought to restore macroeconomic stability, including a reduction in the fiscal imbalance".

\section{Guatemala 2002}

Fiscal consolidation amounted to 1.9 percent of GDP, with tax hikes of 1 percent of GDP and expenditure cuts of 0.9 percent of GDP. The measures were motivated by the need to reduce an inherited deficit. The 2002 SBA request report (EBS/02/49) sheds light on page 5 on the motivations for the fiscal package: "The authorities have framed an economic program for 2002 aimed at strengthening the fiscal position, while helping to achieve the revenue and social expenditure targets of the Peace Accords, and to begin addressing the weaknesses of the financial system". 
On the revenue side, an increase in tax revenues in the order of 1 percent of GDP was expected, reflecting the full-year effect of revenue measures introduced in July and November 2001; the reestablishment of a 10 percent custom duty on gasoline in January 2002; and the increase in excise taxes in February 2002 (see page 13 of EBS/02/49). The 2001 tax measures included: an increase in the VAT rate from 10 to 12 percent; higher income tax rates on commercial and agricultural enterprises; and import duties on used cars. In addition, in November 2001 congress approved an increase in excise taxes for cigarettes (see the Memorandum on Economic and Financial Policies in EBS/02/49). On the expenditure side, an adjustment of 1 percent of GDP would fall on current expenditure, while capital outlays would remain constant as a share of GDP. But Table 6 on page 30 of the 2005 Article IV consultation staff report (IMF Country Report No. 05/362) indicates a different composition of cuts with current primary expenditure falling by 0.4 percent of GDP in 2002 , whereas capital expenditure fell by 0.5 percent of GDP.

\section{Guatemala 2012}

Fiscal consolidation consisted of expenditure cuts of 0.4 percent of GDP. The cuts were motivated by the need to reduce an inherited deficit. The statement by the Executive Director for Guatemala at the end of the 2012 Article IV consultation staff report (IMF Country Report No. 12/146) sheds light on the motivations for the policy actions: "Given the impact on tax collection during the global crisis, the country adopted a countercyclical policy that led to an increase of the fiscal deficit to 3.1 percent in 2009 and 3.3 percent in 2010 . The authorities were fully aware of the importance to return to fiscal discipline and initiated a process of fiscal consolidation by implementing policies aimed at reducing the central Government's deficit to 2.8 percent in 2011 and to further reduce it to 2.4 percent, 2.1 percent and 1.9 percent in 2012, 2013 and 2014, respectively, in order to maintain public debt at sustainable levels in the medium term".

The 2013 Article IV staff report (IMF Country Report No. 13/247) states that the fiscal consolidation that occurred in 2012 was mainly driven by expenditure cuts. As shown in Table 4B of the report, primary expenditures fell by 0.4 percent of GDP in 2012, with a decrease in capital expenditure more than offsetting an increase in current primary expenditure.

\section{Guatemala 2013}

Fiscal consolidation consisted of tax hikes amounting to 1 percent of GDP, as part of the consolidation effort initiated in 2012. The measures were motivated by the need to reduce an inherited deficit as discussed in the entry for 2012. The statement by the Executive Director for Guatemala at the end of the 2012 Article IV consultation staff report (IMF Country Report No. 12/146) sheds light on the motivations for the policy actions:

"Furthermore, our authorities' commitment to fiscal discipline is evinced by the steps taken by the new administration that took office on January 14, 2012 immediately submitting to Congress a tax reform that was approved together with an anti-evasion law ..." . 
The tax reform that was approved in February 2012 broadened the base of corporate and personal income taxes; increased corporate income tax rates on gross income over Q30,000 starting in 2013; and introduced a 5 percent tax on dividends, among other measures. The expected yield of the changes in income taxes was about 0.8 percent of GDP in 2013 . In addition, the vehicle tax and other excise taxes were increased with an expected yield of 0.2 percent of GDP in 2013. The 2012 Article IV consultation staff report (IMF Country Report No. 12/146) presents on page 13 and on Box 3 a description of the measures adopted and their estimated revenue yields. The Estudio de la Economia Guatemalteca report for 2012 elaborated by the Central Bank of Guatemala also discusses the reforms on pages 107 and 108. 


\section{J. Jamaica ${ }^{1718}$}

\section{Jamaica 1992}

Fiscal consolidation consisted of tax hikes of 2.1 percent of GDP. The tax increases aimed at reducing a large inherited deficit. The measures were implemented in the first quarter of calendar year 1992. The 1991 Article IV staff report (EBS/92/56) states on page 6 states that: "In order to attain the revised target for the public sector borrowing requirement for 1991/92, the authorities are seeking to achieve in the final quarter of 1991/92 an overall fiscal surplus (excluding divestment proceeds) of 1.7 percent of GDP in the combined operations of the Central Government and the Bank of Jamaica and a surplus of 1.9 percent of GDP in the rest of the public sector. To this end, the authorities have increased domestic taxes and public sector prices; these adjustments are expected to yield additional revenue of 0.3 percent of GDP and 1.8 percent of GDP, respectively, in the final quarter of 1991/92 (these measures are listed in Table 8 of the Technical Memorandum of Understanding in Annex II)".

\footnotetext{
${ }^{17}$ The fiscal year (FY) in Jamaica runs from April to March. The budgetary impact of all measures is expressed in calendar year terms.

${ }^{18}$ A comprehensive tax package amounting to about 4 percent of GDP implemented in 1993 was more than offset by significant increases in public sector salaries and was therefore excluded from the database. See the 1993 Article IV staff report (EBS/93/137) page 5 and the 1994 Article IV staff report (EBS/95/6) page 2.

Furthermore, in 1998, the Jamaican authorities adopted measures to increase revenues (mainly changes in tax administration) amounting to 3 percent of GDP as well as capital expenditure cuts amounting to 1 percent of GDP. The measures were implemented in the context of a program to reduce inflation, promote growth and maintain high international reserves. See the 1998 Article IV consultation staff report (SM/98/165) pages 17-19 for a discussion. We consider that these measures were motivated endogenous considerations and chose to exclude them from the database (see Section IV for a more detailed description of this episode). In addition, the government introduced tax measures with an expected yield of 3 percent of GDP over the 2009/10 fiscal year, but the tax package seems to have been at least in part motivated by cyclical considerations and was therefore excluded from the database. The 2009 Article IV consultation staff report (IMF Country Report No. 10/267) sheds light on the motivation for the adjustment measures adopted on page 5: "Government finances have deteriorated, constraining the authorities' ability to respond to the global shock with countercyclical policies. During FY2008/09, the public sector deficit widened by 11/4 percent of GDP, to $91 / 2$ percent. During this current fiscal year, faced with declining revenues and a sharp increase in interest costs, the government introduced two packages of fiscal measures equivalent to 1.9 percent of GDP". According to page 5 of the 2010 Memorandum of Economic and Financial Policies: "To safeguard public finances, the government has introduced three packages of measures over the past year, aimed at boosting revenue by over 3 percent of GDP. In the first phase of measures, introduced at the time of the FY 2009/10 budget, the government raised the excise tax on gasoline by J $\$ 8.75$ per litre, and broadened the General Consumption Tax base by eliminating exemptions on several items. The second package, aimed at generating annualized revenue equivalent to 0.3 percent of GDP, became effective on October 1, 2009 and included increasing the GCT rate on telephone services from 20 percent to 25 percent and increasing the departure tax to $\mathrm{J} \$ 1,800$. The third package aimed at generating revenue equivalent to 13/4 percent of GDP, became effective on January 1, 2010 (prior action)". Finally, in July 2016 the first phase of a tax reform aiming at rebalancing the tax structure from direct to more growth-friendly indirect taxes was implemented (IMF Country Report 16/350, page 9). Nevertheless, the reform was designed to be revenue neutral and therefore was not included in the database.
} 
For additional background on the economic context surrounding the consolidation effort see page 34 of the same report: "The economic programme for 1991/92 sought to strengthen the environment for economic growth on a sustainable basis. Real GDP was projected to grow by 3 percent, the same rate as in 1990/91, while the 12-month increase in consumer prices was targeted to moderate from about 28 percent in March 1991 to 19 percent by March 1992. The programme aimed to reduce the external current account deficit (before grants) from an estimated 7 1/2 percent of GDP in 1990/91 to about ...".

The 1992 Request for Extended Arrangement report (EBS 92/179) also discusses on page 3 some of the policy actions: "Under the stand-by arrangement which expired in September 1992, Jamaica continued to implement key reforms aimed at improving the public finances and increasing overall economic efficiency.... On October 22, 1991, the tax system was restructured through the replacement of a large number of taxes by a General Consumption (value-added) Tax (GCT)".

\section{Jamaica 1999}

Fiscal consolidation consisted of expenditure cuts of 0.7 percent of GDP on a net basis. The cuts aimed at reducing debt. The 1999 Article IV consultation staff report (IMF Country Report 00/8) discusses in the executive summary the authorities' strategy: "The staff is of the view that the core problems facing Jamaica are the heavy public debt burden, high real interest rates and weak external competitiveness that have constrained productive investment and growth, and the large fiscal imbalance. The authorities agreed that the first two problems are central to Jamaica's difficulties, but do not believe that there is a major competitiveness problem. They, therefore, considered inappropriate a policy framework that would include a sharp adjustment in the exchange rate .... The strategy that authorities have adopted centers around moderate improvements in the primary fiscal balance, and a continuation of tight monetary policy."

Page 6 of the same report indicates that contractionary fiscal measures were introduced in April-May 1999. The same report discusses on pages 11 and 12 expectations that central government tax revenue would increase by 2 percent of GDP due to improvements in tax administration, an increase in excise taxes, and the introduction of a withholding tax on interest income. On the expenditure-side, page 12 of the report highlights a nominal wage freeze in the public sector, which is expected to yield savings of 0.2 percent of GDP.

Table 2 on page 23 of the 2001 Article IV staff report (EBS/01/73) confirms an increase in central government tax revenues of 2 percent of GDP, whereas primary current expenditure fell by 1.1 percent of GDP and capital expenditure increased by 0.4 percent of GDP. Nevertheless, page 7 of the same report suggests that a large part of the improvement in revenues was linked to cyclical factors: "After widening dramatically to 11 percent of GDP in 1998/99, the public sector deficit declined by 4 percentage points of GDP in 1999/00. The bulk of this adjustment occurred in the central government, reflecting the impact of a number 
of temporary factors that boosted revenue (from bauxite and cellular license fees), as well as declines in noninterest current expenditure".

Therefore, it appears that a large share of the improvement in revenues was linked to cyclical and temporary factors. In this context, we chose not to include the revenue increase in the estimate of the size of the action-based consolidation. measure. We include the net 0.7 percent of GDP decrease in expenditure (1.1 percent of GDP in primary current expenditure minus the 0.4 percent of GDP increase in capital expenditure) in our database.

\section{Jamaica 2000}

Fiscal consolidation consisted of expenditure cuts of 1.8 percent of GDP. The cuts aimed at reducing debt. Paragraph 10 of the July 19, 2000 Memorandum of Economic and Financial Policies of the Government of Jamaica for 2000/01 2001/02 presents the main objectives of the authorities' program: "The government is strengthening its adjustment strategy to accelerate the reversal in the adverse debt dynamics and put the economy on a less vulnerable path. .... In this regard, the medium-term macroeconomic framework has as a central purpose a significant reduction in the public sector borrowing requirement that would contribute importantly in the reduction of domestic interest rates. ... The goal is to reduce the debt-to-GDP ratio significantly over the medium term, which would require that sizeable public sector primary surpluses be maintained over the period". The 2001 Article IV consultation staff report (EBS 01/73) confirms on page 5 the program objective of reversing adverse debt dynamics.

The reduction in the deficit would be achieved through expenditure restraint (both on capital and current expenditures); an increase in the withholding tax rate on interest as well as new fees and charges; and measures to broaden the base of the sales tax (GCT). Nevertheless, footnote 23 on page 13 of the 2001 Article IV consultation staff report (EBS 01/73) suggests that the planned revenue base-broadening measures were not implemented. In fact, Table 4 on page 29 of the 2002 Article IV consultation staff report (EBS 02/134) indicates that tax revenue was unchanged as a share of GDP in 2000/01 relative to 1999/00. Current primary expenditures fell by about 1.6 percent of GDP over the same period and capital expenditures by 0.2 percent of GDP.

\section{Jamaica 2003}

Fiscal consolidation amounted to 3 percent of GDP, with tax hikes of 1.5 percent of GDP and expenditure cuts of 1.5 percent of GDP. The measures were motivated by a need to reduce the deficit to restore policy credibility. On the motivation for the fiscal consolidation, see the 2003 Article IV staff report (IMF Country Report 04/76) page 4: "Authorities are aiming at a strong upfront fiscal adjustment to restore policy credibility and help stabilize the foreign exchange market". Page 14 of the same report states that: "The authorities recognize that their continued access to international capital markets depends on the credibility and implementation of the budget". The 2004 Article IV staff report 
(SM/04/254) provides further details on the economic context of the adjustment on page 4: "Fiscal slippages and a worsening external current account position led to acute pressures in the foreign exchange market in FY 2002/03 and early FY 2003/04 ... In response, the Bank of Jamaica (BOJ) sharply increased interest rates on its open market instruments to around 35 percent. Higher interest rates and depreciation contributed to a marked increase in the public debt-to-GDP ratio, which peaked at 1461/2 percent in FY 2002/03”.

The 2003 Article IV staff report (IMF Country Report 04/76) describes the key revenue measures envisaged in the budget on page 14. They included a 4 percent surcharge on all imports; a widening of the tax base for the general consumption tax and higher duties on vehicle imports. But the report states that no measures were contemplated on the expenditure side in the FY 2003/04 budget, as authorities saw “... little scope for large expenditure cuts or reductions in wages". The 2004 Article IV staff report (SM/04/254) confirms the implementation of tax measures on page 7: "The primary surplus (excluding privatizationrelated receipts) increased by 4 percentage points of GDP, to 11 percent of GDP, compared to 7 percent of GDP in FY 2002/03 (Table 2). Revenue increased by about 2 percentage points of GDP, to 30 percent of GDP, reflecting higher receipts from the general consumption tax, personal income tax, and taxes on interest as a result of measures introduced in the FY 2003/04 budget, as well as the imposition of an import surcharge". But the report also points to cuts in primary expenditures: "Primary expenditure declined by 2 percentage points, to 19 percent of GDP, as cuts in nonwage current spending and capital outlays were implemented."

Given the timing of the implementation of the tax package and Jamaica's fiscal year, we assign $3 / 4$ of the budgetary impact of the measures to calendar year 2003 and the other $1 / 4$ to calendar year 2004 .

\section{Jamaica 2004}

The fiscal consolidation initiated in 2003 and continued in 2004, with tax measures totaling 0.5 percent of GDP and expenditure cuts totaling 0.5 percent of GDP. Fiscal consolidation was motivated by a need to reduce the deficit to restore policy credibility (see entry for 2003 above).

\section{Jamaica 2012}

Fiscal consolidation consisted of tax hikes amounting to 0.8 percent of GDP. The tax increases were motivated by the need to reduce debt. The measures were enacted in the third quarter of 2012. The 2013 EFF request report (IMF Country Report 13/126), sates on page 4 that: "The 2011 Article IV Consultation, completed in May 2012, presented a comprehensive package of measures to promote growth and lower fiscal imbalances. It advocated strong and upfront fiscal adjustment to put debt on a decisive downward trajectory. To support growth, it called for measures to boost competitiveness, including structural reforms as well as greater exchange rate flexibility. During 2012/13 the authorities began to tighten fiscal 
policy. The government that took office in January 2012, with a large majority in parliament, introduced a budget for fiscal year 2012/13 that aimed at raising the central government's primary surplus to 6 percent of GDP, from 3.2 percent in the previous year. A tax package, with a full-year effect estimated at 1.6 percent of GDP was enacted during the second quarter of the fiscal year, as the cornerstone of the budget measures".

Given the timing of the implementation of the tax package, we assign half of the full year impact of 1.6 percent of GDP to calendar year 2012 and the other half to calendar year 2013.

\section{Jamaica 2013}

Fiscal consolidation amounted to 2.6 percent of GDP, with tax hikes of 2 percent of GDP and expenditure cuts of 0.6 percent of GDP. The measures were motivated by the need to restore debt sustainability and strengthen public finances. The $2013 \mathrm{EFF}$ request report (IMF Country Report 13/126) states on page 5 that: “The authorities' four-year economic program, for 2013/14 through 2016/17, seeks to avert immediate crisis risks and create the conditions for sustained growth through a significant improvement in the fiscal balance, debt position, and competitiveness."

The same report on page 8 describes the consolidation measures: "A new tax package is expected to generate 1.6 percent of GDP in revenues for the central government. It includes measures to broaden the tax base and equalize rates as well as ad hoc increases in rates and fees. To allow for a full-fiscal year effect, the measures were announced in a supplementary budget in February 2013”. “... In the draft 2013/14 expenditure budget, the authorities have proposed specific expenditure reductions of about 0.8 percent of GDP'. These included reductions in the wage bill ( 0.4 percent of GDP), cuts in transfers to local governments $(0.2$ percent of GDP), and measures yielding efficiency gains (0.2 percent of GDP). The 2014 Article IV staff report (IMF Country Report 14/169) confirms that the consolidation package was implemented (see page 5).

Given the timing of the implementation of the consolidation package and Jamaica's fiscal year, we assign $3 / 4$ of the impact to calendar year 2013 and the other $1 / 4$ to calendar year 2014 . Therefore, the budgetary impact of tax measures in 2013 would be 2 percent of GDP with 0.8 percent of GDP linked to the 2012 tax package (see 2012 entry above) and 1.2 percent of GDP $(0.75 * 1.6)$ linked to the 2013 package. Similarly, the budgetary impact of the expenditure cuts in 2013 would be 0.6 percent of GDP $(0.75 * 0.8)$.

\section{Jamaica 2014}

The fiscal consolidation initiated in 2013 and continued in 2014, with tax measures totaling 0.4 percent of GDP and expenditure cuts totaling 0.2 percent of GDP. Fiscal consolidation was motivated by need to restore debt sustainability and strengthen public finances (see entry for 2013 above). 


\section{K. Mexico $^{19}$}

\section{Mexico 1989}

Fiscal consolidation consisted of tax hikes amounting to 0.9 percent of GDP. The tax increase was motivated by the need to reduce the fiscal deficit. The 1990 Recent Economic Developments report (SM/90/169), states on page 17 that: "In 1989, the authorities adopted a fiscal program, supported by the Fund under an extended arrangement, which sought to strengthen the public finances." The 1989 Article IV staff report (EBS/89/91) states on page 19 that: "In early 1989 the Mexican authorities adopted major revisions to the tax system and accelerated the implementation of the fiscal reforms adopted in 1987. The main measures were (a) the system of dividend deduction was abolished and replaced by a tax on corporate dividends at the source with a view to preventing tax evasion while distributed dividends will be subject to a further tax in order to promote reinvestment; (b) the corporate income tax rate was reduced from 39.2 percent to 37 percent: (c) a minimum 2 percent tax. which can be credited against income tax liabilities. was introduced on firms' assets: (d) the number of personal income tax brackets was reduced from 12 to 6 with a substantial reduction in marginal tax rates; and (e) the dispersion in import tariffs was narrowed by increasing the minimum tariffs for most items to 10 percent, except for some basic foodstuffs and medicines, while maintaining the maximum rate at 20 percent". Page 23 of the same report states that: "The fiscal measures described above (Section III.1.c.), together with stricter enforcement of tax collection, are expected to yield a net increase of 0.9 percentage point of GDP in tax revenue".

In addition, the 1990 Recent Economic Developments report (SM/90/169) states on pages 21 and 24 that: "In 1989, total revenue increased by about 2 percentage points of GDP, about half of which was attributable to a strong rise in tax revenue and the rest to profit transfers from the Bank of Mexico. The increase in tax revenue reflected the revisions to the tax

\footnotetext{
${ }^{19} \mathrm{An}$ increase in the general VAT tax rate from 10 to 15 percent effective as of May, was one of the most prominent adjustment measures in 1995. The adjustment was undertaken in the context of an IMF-supported program. The estimated impact of this increase in the VAT was of 1.2 percent of GDP (see page 7 of the first 1995 SBA review report, EBS/95/47). Moreover, adjustments to public sector prices were projected to generate revenues of 0.3 percent of GDP. In addition, cuts in primary expenditures in the order of 1.4 percent of GDP were implemented (see Table 3 on page 29 of the 1997 Article IV staff report, SM/97/201), in particular, reductions on the wage bill ( 0.7 percent of GDP) and capital expenditures ( 0.6 percent of GDP). But these adjustment measures were driven by current and prospective economic conditions as discussed on page 2 of the 1995 Article IV consultation staff report (EBS/95/103) on page 2. Hence, we chose to exclude the measures from the database (see Section IV for a more detailed description of this episode). Gunter et al. (2017) also flag the VAT hike as endogenous.

Tax measures were also adopted in December 2001 with an expected yield of 1 percent of GDP, but the package was fully allocated to finance additional social expenditure and investment (IMF Country Report $02 / 237$, page 15) and therefore these measures were excluded from the database.

Another fiscal reform package was approved in September 2007 with an estimated revenue gain of 1 percent of GDP, but it was also linked to expenditure increases (IMF Country Report 07/379, pages 25 and 27) and therefore excluded.
} 
system, particularly the change in the system of taxing dividends, the introduction of a general 2 percent tax on the assets of all businesses and the increase in the minimum tariff on imports to 10 percent in order to reduce dispersion."

\section{Mexico 2010}

Fiscal consolidation consisted of tax hikes amounting to 0.6 percent of GDP. The measures were motivated by the long-run considerations because of a structural decline in oil production. The 2010 Article IV staff report (IMF Country Report 10/71) presents the motivation for the reform on page 16: "The 2010 budget includes an important tax package of about 1 percent of GDP to offset the deterioration in the structural revenue position linked to the decline in oil production. ... The fiscal tightening will also help stabilize public debt and set the stage for its gradual reduction over the next years." Page 31 of the same report states further that: "The tax reform included in the 2010 budget is a welcome step in assuring fiscal sustainability. It is a testament to the authorities' commitment to sound policies that they were able to build consensus for these measures in the midst of a sharp slowdown."

Therefore, we consider that the reform was motivated by long-run considerations, as it seeks to respond to a structural (rather than cyclical) decline in oil production. Nevertheless, Gunter et al. (2017) flag it as an endogenous tax increase (GDP-driven).

The 2010 Article IV staff report (IMF Country Report 10/71) presents details of the reform package on page 19. It consisted of an increase by 1 percentage point in the standard VAT rate to 16 percent, as well as increases in excise taxes, changes in the tax treatment of losscarry forwards, and a temporary increase in income tax rates. It states that: "The resulting permanent revenue increase (about $2 / 3$ of the entire reform or 0.6 percent of GDP) delivers important consolidation".

\section{Mexico 2014}

Fiscal consolidation consisted of tax hikes amounting to 0.6 percent of GDP. The tax increases were approved in October 2013 and effective as of 2014, motivated by the long-run goal of reducing dependency on oil revenues. The 2013 Article IV staff report (IMF Country Report 13/334) states on page 16 that: "Congress also approved a tax reform that moderately raised non-oil tax revenue and phased out subsidies on domestic sales of gasoline to try to reduce the dependence on oil revenues. Key tax measures include the extension of the 16 percent value-added tax to firms in border regions and an increase in income tax by broadening the tax base and applying higher tax rates to high income earners. The reform also includes an 8 percent 'junk food' tax and a mining tax." According to the same report, the tax reform, which was approved in October 2013 and effective as of 2014 would: “... raise non-oil tax revenues from 10.0 percent of GDP in 2013 to 10.6 percent by 2017-18."

A detailed description of the reform measures is also presented on pages 74 to 83 of the Criterios Generales de Politica Económica report for 2015 elaborated by the Mexican 
Ministry of Finance. The increase in revenues presented in this report is expected to occur over a much shorter horizon than the one considered in the Article IV report with non-oil tax revenues reaching 10.7 percent of GDP by 2015. Page 191 and the Table on page 192 of the same report indicate that the revenue impact of the reforms in 2014 would amount to 0.6 percent of GDP mostly due to increases in VAT and excise taxes collections (including the new taxes on 'junk food').

\section{Paraguay $^{20}$}

\section{Paraguay 1989}

Fiscal consolidation amounted to 2.6 percent of GDP with tax hikes of 2 percent of GDP and expenditure cuts of 0.6 percent of GDP on a net basis. The measures were motivated by the need to reduce the fiscal deficit. The 1989 Article IV staff report (SM/89/274) states on page 10 that: "The authorities explained that they attach high priority to the correction of existing fiscal imbalances". Moreover, the 1991 Article IV staff report (SM/91/160) states on page 2 that: "To address the country's economic imbalances, the Government that took office in 1989 tightened fiscal and credit policy, unified the exchange rate under a managed float, and liberalized the financial and trade systems. In the fiscal area, the authorities increased government revenue, raised public tariffs, improved the operational efficiency of public enterprises, and reduced investment spending. In addition, they took steps to improve tax administration and combat evasion."

The 1989 Article IV staff report (SM/89/274) states on pages 3 and 5 that: "The ratio of tax revenue to GDP would rise from 7 percent of GDP in 1988 to an estimated 9 percent of GDP in 1989, owing to the adjustment of the exchange rate used to compute taxes on imports and

\footnotetext{
${ }^{20}$ Fiscal adjustment measures were adopted in 1990 in the context of a program to reduce inflation and build-up international reserves. We consider that the adjustment was a direct response to economic conditions and hence we excluded this episode from the database (see Section IV for a more detailed discussion of this episode). The 1991 SBA request report (EBS/91/5) presents on pages 5 and 6 the motivations for the program. The operating surplus of public enterprises increased by 2.1 percent of GDP, whereas tax revenue remained broadly constant as a share of GDP. Moreover, public sector expenditure fell by about 1 percent of GDP (of which about 0.6 percent of GDP were cuts in current expenditure). In addition, A new administration took office in August 1998 and implemented a number of measures to increase revenue for the rest of the year, including increases in excise duties and tax administration improvements. The motivation for policy measures adopted seems to be related to current economic conditions (especially a slow-down in economic activity and trade with Brazil) as discussed on page 9 of the 1999 Recent Economic developments report (IMF country report 99/10). Hence, we chose to exclude this episode from the database (see Section IV for a more detailed discussion of this episode). Moreover, a tax reform introducing a personal income tax (motivated by long-run considerations) was enacted in July 2012, but was accompanied by an increase in current expenditures, in particular wages (see Table 1 on page 29 of the 2013 Article IV staff report, IMF Country Report 14/60). The 2012 Article IV staff report (IMF Country Report 12/211) states on page 14 that: "The PIT was originally approved in 2004 but its implementation has been postponed several times by congress." The original estimates of the impact of the introduction of the PIT were between 0.2 to 0.3 percent of GDP (IMF Country Report 10/170).
} 
foreign exchange transactions, the introduction of temporary export taxes, and the increase in property tax collections". These measures were implemented after the new government took office at the end of the first quarter of 1989.

The 1991 SBA request (EBS/91/5) states on pages 3 and 4 that: "The authorities have tightened the stance of fiscal policy considerably, through a combination of sharp cuts in public sector capital spending, increases in government revenue, adjustments in public tariffs and improvements in the operational efficiency of public enterprises. They also have taken steps to improve tax administration and combat evasion, including the unification of tax collection agencies under a new Undersecretariat for Taxation at the Ministry of Finance and the introduction of a single taxpayer registry. As a result, the combined public sector position shifted from a deficit of $3 \frac{1}{2}$ percent of GDP in 1988 to a surplus of $1 \frac{1}{2}$ percent of GDP in 1989."

Table 2 on page 12 of the 1994 Article IV staff report (SM/94/80) suggests that tax revenues increased by about 2 percent of GDP and public sector (including public enterprises) capital expenditures declined by 3.1 percent of GDP in 1989. But the decline in capital expenditure was partly offset by an increase in current expenditure of 2.5 percent of GDP (including interest payments). ${ }^{21}$ Therefore, we chose to include in the database a net effect of 2.6 percent of GDP due to the tax measures ( 2 percent of GDP linked to the revenue package plus the 0.6 percent of GDP net decrease in expenditure).

\section{Paraguay 2001}

Fiscal consolidation amounted to 1.8 percent of GDP with expenditure cuts of 1.3 percent of GDP and tax hikes of 0.5 percent of GDP. The fiscal measures were motivated by the need to reduce the deficit. The 2001 Article IV staff report (IMF Country Report $\mathrm{SM} / 01 / 125)$ states on page 10 that: "The government intends to reduce the central administration's deficit in 2001 to about half the nominal level registered in 2000, which is consistent with the noninflationary financing that would be available. This is equivalent to a reduction from 4.5 percent of GDP to 2.0 percent of GDP, to be achieved primarily through adjustments in the expenditure of the central government, which would decrease by around 2.2 percentage points of GDP, and to a lesser extent through revenue measures. Expenditure restriction would come from reforms aiming at a leaner and more cost-effective civil service and from a more moderate level of public investment. Public sector wages will be frozen in nominal terms and public employment will be restricted, while overtime pay would be curtailed sharply. Spending on goods and services would also be curtailed, with interest payments expected to benefit from lower LIBOR rates. Capital spending would be scaled

\footnotetext{
${ }^{21}$ Historical data from the Situacion Financiera for the central government downloaded from the Ministry of Finance website (http://www.hacienda.gov.py/situfin/) indicates that interest payments for the central government remained broadly constant as a share of GDP in 1989 relative to 1988.
} 
back from the very high levels of 1999 and 2000, which had been made possible by the extraordinary external finance available during those years".

The report also states that: "Revenues of the central government are expected to increase by around $1 / 2$ percentage point of GDP in 2001, reflecting changes already adopted in the tax system, including increases to the excise tax on diesel in late 2000 and early 2001; the elimination of a facility that permitted banks to deduct increases in their required capital from profits; the inclusion of transport and personal services in the VAT tax base; and the elimination of VAT exemptions on goods In the re-export trade".

The 2002 Article IV staff report (SM/03/76) suggests in Box 2 of page 24 that expenditure cuts implemented in 2001 were significantly lower than what had been originally announced: "In the fiscal area, spending restraint reduced expenditures by 1.3 percentage points of GDP in 2001, but the deeper reforms of the central government and the public employees' pension plan did not occur".

\section{Paraguay 2003}

Fiscal consolidation consisted of tax hikes of 1.25 percent of GDP. The tax increases were motivated by the need to reduce public debt. The 2003 SBA program request document (IMF country report $04 / 66$ ) states on page 8 that: "The authorities explained that the size and timing of the fiscal adjustment was determined by several factors: (i) the need to reduce public debt to a more sustainable level; (ii) the authorities' desire to take advantage of the momentum of the new government's post-election support to front-load the adjustment process; and (iii) the need to close the substantial financing gaps in 2003 and 2004 and eliminate arrears".

The fiscal package included an increase in excise taxes from 14 to 20 percent in August yielding 0.5 percent of GDP in revenues annually, as well as an overhaul of tax and customs administration expected to yield 1 percent of GDP in 2003. The main features of the package are also described in the memorandum of economic and financial policies on page 60 of the 2003 SBA program request document.

Given the timing of implementation of the increase in excise duties, we assign half of the budget impact ( 0.25 percent of GDP) to 2003 and the rest to 2004. The full impact of the remaining measures ( 1 percent of GDP) is assigned to 2003.

\section{Paraguay 2004}

Tax reform (Administrative Reorganization and Fiscal Adjustment Law) and other revenue measures with an estimated budgetary impact of 0.8 percent of GDP. The reform was motivated by need to reduce the deficit and increase efficiency. The reform was part of the SBA program with the IMF. The 2003 SBA program request document (IMF country report $04 / 66$ ) states on page 6 that the economic program: “... aims to stabilize the 
fiscal situation and the banking system and to initiate needed structural reforms. The program will require a sizable fiscal effort to reduce the deficit and clear arrears ...".

The memorandum of economic and financial policies on page 60 in the same report states that: “... Tight controls on current spending in the 2004 budget, expected to produce savings of 0.2 percent of GDP ...”. But the first SBA review document (IMF Country Report 04/294) seems to indicate on page 7 that amendments to the budget by congress have eliminated these estimated savings provided by the planned expenditure cuts: "The 2004 budget, approved by Congress in December, contains spending somewhat higher than that envisaged in the program. However, the authorities assured the staff that the fiscal objectives will be met by prudent budget execution."

The same report states that the excise tax on diesel was increased by another 6 percentage points in January 2004 with an expected revenue yield of 0.25 percent of GDP and a tax of 2 percent was imposed on soy exports with an expected yield of 0.2 percent of GDP in 2004 . The latter was billed as a temporary measure.

The 2004 Article IV consultation staff report (IMF country report 05/59) on page 13 states that: "On June 25, Congress approved the Administrative Reorganization and Fiscal Adjustment Law, a performance criterion under the SBA, and a crucial piece of legislation for assuring the continuity of responsible fiscal policy. ... The potential revenue yield of the law (if all tax were placed at their legal maxima) has been reduced from $2 \frac{1}{2}$ percent of GDP to $1 \frac{1}{2}$ percent of GDP, but the actual expected yield (based on the authorities' intended tax rates) will be near original estimates. The law eliminates most exemptions to the corporate income tax while reducing the rate, broadens the base of the VAT, institutes a new personal income tax (to be phased in over time), and institutes a new agricultural income tax to replace the previous IMAGRO tax. It also adjusts some excise tax rates, and strengthens legal authority for tax administration. The details of the law, as well as calculations of its yield, are found in Box 4 and Table 16".

The implementation of several measures (such as the introduction of the personal income tax), where significantly delayed or were spread over several years. The revenue yield of applying the tax reform law in 2004 is estimated at 0.1 percent of GDP (see Table 16 of the report). Hence, taking these factors into account, we calculate the overall impact of tax changes in 2004 by taking into account the changes in excise taxes on diesel $(0.25$ percent of GDP), the export tax ( 0.2 percent of GDP), the effects of applying the tax reform ( 0.1 percent of GDP), and the budgetary impact of the 2003 increase in excise duties $(0.25$ percent of GDP, see the entry for 2003). 


\section{Paraguay 2005}

Tax cuts amounting to 0.6 percent of GDP, part of the 2004 Administrative

Reorganization and Fiscal Adjustment Law. The measures were motivated by long-run considerations. The 2004 law was a key measure under the SBA program with the IMF. These tax cuts implemented in 2005 comprised the elimination of the export tax on soy, effective as of February, (IMF Country Report 06/30, page 11, footnote 7) with an estimated revenue loss of 0.2 percent of GDP and the reduction of the corporate income tax (CIT) rate from 30 to 20 percent (see IMF Country Report 06/100, page 5, footnote 2) effective as of August, with an estimated revenue loss of 0.4 percent of GDP for 2005. The estimated revenue impact of the CIT rate change is presented in Table 16 of IMF Country Report $05 / 59$.

There were also expenditure cuts in 2005, but according to IMF Country Report 06/302 page 8 these were linked to cyclical considerations: "The better-than-programmed performance is due to strong tax collections (despite lower rates for the profit tax), low investment project implementation and across-the-board expenditure cuts made in the last quarter of 2005 to help address inflationary concerns."

\section{Paraguay 2006}

Tax cuts amounting to 0.7 percent of GDP, a part of the 2004 Administrative Reorganization and Fiscal Adjustment Law. The measures were motivated by long-run considerations. The 2004 law was a key measure under the SBA program with the IMF. The tax cuts comprised a further reduction of the CIT from 20 to 10 percent. The CIT rate change was effective as of August. The estimated revenue impact of the CIT rate change was a reduction of 0.7 percent of GDP. It is presented in Table 16 of IMF Country Report 05/59. But IMF Country Report 06/100, page 5, footnote 2, presents higher estimates in the order of 1.2 percent on an annual basis.

\section{Paraguay 2014}

A tax reform with an estimated revenue yield of 0.2 percent of GDP. The reform was motivated by long-run considerations. Table 1 on page 29 of the 2013 Article IV staff report (IMF Country Report 14/60) contains a description of the tax reform extending the VAT (at a reduced rate of 5 percent) to primary production and introducing a new agricultural income tax (IRAGRO) of up to 10 percent. The measures were enacted in October 2013 and applied as of January 2014. Page 7 of the same report states that: "Congress has supported the government's reform strategy by approving key laws. To broaden the tax base, on top of the new personal income tax, Congress approved in October 2013 a revamped tax on agricultural income and a generalized VAT to include unprocessed agricultural products."

Moreover, the 2014 Informe de Finanzas Publicas de la Republica del Paraguay (IFP) sheds further light on motivations for the new taxes on pages 61 and 62. In particular, the IFP report states on page 61 that: "These measures seek to increase the formalization of the 
agriculture and livestock sectors, to integrate the agricultural value chains in the tax system, to allow primary producers to deduct the VAT from their costs, to give further incentives to the formation of value chains, to level the playing field between agricultural incomes taxes and general corporate income taxes, and to broaden the tax base". Thus, the introduction of the taxes does not seem to be linked to specific cyclical considerations. IMF staff estimates the impact of the implementation of these measures to be around 0.24 percent of GDP (see David, 2017).

\section{Paraguay 2016}

Fiscal consolidation consisted of cuts in current expenditure amounting to 0.8 percent of GDP. The expenditure cuts were implemented to comply with the deficit ceiling under the country's fiscal responsibility law (FRL). The deficit ceiling of 1.5 percent of GDP under the FRL is defined in "headline" terms (i.e. non-structural, not adjusted for cycles or one-offs). The reduction of 1.1 percent of GDP in primary expense (especially a decrease of the wage bill in real terms) was partly offset by increases in investment in the order to 0.3 percent of GDP. The 2017 Article IV staff report (IMF country report 17/233) states on page 5 that "Fiscal policy has been characterized by restraint in current expenditures and a shift towards capital spending. The deficit outturn of 1.4 percent of GDP last year complied with the Fiscal Responsibility Law (FRL), implying a policy tightening. The authorities offset weakening revenues and higher investment with current expenditure cuts, especially compensation." See also Table 2 on page 33 of the same report. 


\section{Peru'22}

\section{Peru 1992}

Fiscal consolidation consisted of tax hikes amounting to 1 percent of GDP. The measures were introduced in November 1991 with the objective of reducing domestic financing needs of the public sector. The measures were taken in the context of a Rights Accumulation Program with the IMF. The 1992 Article IV staff report (EBS 93/12) states on pages 2 and 3 that: “... Government that took office in August 1990 immediately moved to stabilize the economy. It adopted measures to eliminate the domestic financing requirement of the public sector, remove distortions, and open the economy to foreign competition."

The same report states on page 3 that: "In November 1991 the Government began to introduce a number of tax measures, including an increase in the rate of the value added tax (VAT) from 16 percent to 18 percent and a broadening of its base, increases in the rates of several excise taxes, and the elimination of certain deductions to the corporate income tax. As a result of these measures and continued efforts to strengthen tax administration as well as expenditure restraint, the deficit is estimated to have been reduced further to $2 \frac{1}{2}$ percent of GDP in 1992 (compared with the program target of 31/4 percent)."

In addition, the 1991 Article IV consultation staff report (EBS/91/141) sheds light on the estimated impact of the tax reform on page 17: "The Government plans to submit to Congress further key tax reforms for approval before October 1991 which are expected to help boost revenues to 9.0 percent of GDP in 1992". This would imply an increase in tax revenue of 1 percent of GDP relative to the estimates for 1991 presented in the same report.

\section{Peru 2002}

Fiscal consolidation consisted of tax hikes of 0.2 percent of GDP. A tax reform was enacted in the second half of 2002 with several measures taking effect in 2003 , motivated by a need to reduce debt. The tax reforms were introduced in the context of a Stand-By arrangement with the IMF. The 2004 Article IV staff report (EBS/04/18) states on page 6 that: "A new consolidation effort, supported by the current SBA, began under the new government that took office in July 2001, returning public debt ratios onto a declining path." The same report states on page 4 that: "Ongoing fiscal consolidation aims at ensuring

\footnotetext{
${ }^{22}$ A 1993 tax reform, in the context of a stabilization program supported by the IMF, with an estimated revenue yield of 1.6 percent of GDP, was fully offset by increases in capital and current expenditures (see EBS/94/137, pages 7 and 13 and EBS/95/177 pages 2 and 14) and therefore excluded from the database.

In addition, in mid-2014 Peruvian authorities announced several tax cuts leading to an estimated revenue loss of 0.7 percent of GDP in 2015 as well as expenditure increases. These measures were not included in the database because they were driven by short-term stabilization motives. According to the 2015 Selected Issues Paper (IMF Country report 15/134, page 61): "The objective was to spur domestic demand, further streamline regulations, and ease the tax burden in several tax categories". See also Box 1 in the 2015 Article IV consultation staff report (IMF country report 15/133) and page 6 and Box 8.1 of the 2016-18 Marco Macroeconomico Multinaual report.
} 
sustainable debt dynamics under robust assumptions". The 2002 Article IV staff report (EBS/02/199) states on page 8 that: "A number of tax reforms were implemented (with IMF/World Bank technical assistance) and are expected to yield 0.8 percent of GDP on an annual basis. These reforms include steps to broaden the income tax base, rationalize excise taxes on petroleum products, narrow the scope of future tax-stability contracts, eliminate certain VAT exemptions, and strengthen tax audit programs (see Appendix VI).”

The same report on page 64 states that: "The tax reform in 2002 included tax policy and tax administration measures. Tax policy measures were intended to improve the neutrality of the tax system and increase tax bases. Measures concentrated on: (i) income taxes (which will take effect in 2003); (ii) elimination (or restriction) of some VAT exemptions; and (iii) increase in the kerosene excise. On tax administration, measures aimed at reducing tax evasion by: (i) introducing various systems of VAT withholding; (ii) intensifying the control of tax collection, refunds and rebates; and (iii) ensuring the collection of tax debts from government's suppliers and private companies. As a result of the measures implemented, tax revenue is expected to increase by 0.2 percent of GDP in the second half of 2002 and 0.8 percent of GDP in 2003".

\section{Peru 2003}

Fiscal consolidation initiated in 2002 continued in 2003, with tax measures totaling 0.8 percent of GDP. Fiscal consolidation was motivated by a need to reduce debt (see entry for 2002 above).

\section{Peru 2011}

Tax cuts, partly offset by tax administration measures and the effects of a new framework for mining taxation, leading to a net revenue loss of 0.39 percent of GDP. The tax cuts were motivated by long-run considerations. In March-April 2011 a number of tax measures were adopted that would result in a decrease in the tax burden. Pages 67 and 68 of the 2012-2014 Marco Macroeconomico Multinaual report published by the Peruvian Ministry of Finance describe the measures and their estimated impact. They include reductions in trade tariffs in December 2010 and April 2011, motivated by the need to improve consumer welfare and increase the efficiency of resource allocation. It is estimated that the tariff reductions would have an impact of S/. 700 million in 2011 (0.15 percent of GDP).

Moreover, the authorities implemented a reduction in the general sales tax by one percentage point with estimated impact of S/. 1600 million in 2011 (about 0.34 percent of GDP) motivated by the desire to decrease disincentives to formalization. In April 2011, the authorities also reduced the financial transactions tax with the objective of minimizing the negative effects of this tax on financial inclusion and on the competitiveness of firms. The estimated revenue loss linked to this measure is $\mathrm{S} / .700$ million in 2011 (0.15 percent of GDP). 
These tax cuts were partly offset by tax administration measures that would increase revenue collections by S/. 570 million in 2011 ( 0.12 percent of GDP) as well as the impact of the new mining taxation regime. Box 2 on page 14 of the 2011 Article IV consultation staff report (IMF Country Report No. 12/26) discusses the mining taxation reform and its objectives: "The mining taxation reform, approved in September, 2011, would increase progressiveness and public revenues, while preserving competitiveness of the sector". The reform included a new royalties system based on operating profits; a new special mining tax; and a special (voluntary) levy. The revenue yield of the new regime is estimated at about 0.5 percent of GDP annually.

On the expenditure side, the 2013-15 Marco Macroeconomico Multinaual report suggests on page 22 that the reductions observed in 2011 were motivated by cyclical considerations to prevent overheating of the economy and rebuild fiscal space. Delays in the execution of public investment plans were a significant factor in driving the fall in expenditure as a share of GDP, despite measures taken in the second half of the year to boost execution in part as a response to the deterioration of the international economic situation with sovereign stress in European countries. For these reasons, we do not include the expenditure cuts in our database.

Taking these factors into account, we assign a net effect of 0.39 percent of GDP in 2011 to the tax cuts. We consider the impact of the reductions in trade tariffs, the financial transactions tax and the general sales tax ( 0.63 percent of GDP), which is partly compensated by tax administration measures ( 0.12 percent of GDP) and the effect of the new mining taxation framework implemented in the last quarter of the year $(0.5$ percent of GDP annually or 0.13 percent of GDP in 2011). We also assign a revenue increase of 0.38 percent of GDP to 2012 to reflect the full year impact of the new mining taxation regime $(0.5-0.13)$.

\section{Peru 2012}

Tax increases initiated in 2011 as part of the new mining taxation regime, totaling 0.38 percent of GDP. The new mining taxation regime aimed at increasing the progressiveness and public revenues, while preserving competitiveness of the sector (see entry for 2011 above). 


\section{N. Uruguay ${ }^{23}$}

\section{Uruguay 1990}

Fiscal consolidation consisted of tax increases amounting to 1.7 percent of GDP. The measures were motivated by the need to reduce a large inherited deficit. The tax hikes were implemented in March/April 1990, in particular an increase of the VAT rate by 1 percentage point. The increase in the VAT rate was also flagged as exogenous to cyclical considerations by Gunter et al. (2017). There were also measures to curb expenditure, including cuts in investment by the general government amounting to 0.5 percent of GDP, and a reduction in real wages in the public sector amounting to 0.3 percent of GDP (see the 1991 Recent Economic Developments report SM/91/183), but these were more than offset by expenditure increases elsewhere.

The 1991 Article IV staff report (SM/91/168) states on page 2 that: "In addition to high inflation and sluggish economic activity, the administration that took office in March 1990 was confronted with a combined public sector deficit that had risen from 5 percent of GDP in 1988 to over 7 1/2 percent of GDP in 1989 and the first quarter of $1990 \ldots$... Upon assuming office, the authorities adopted corrective measures, including a sharp increase in public sector tariffs and a fiscal package with increases in many tax rates and the introduction of new taxes." The 1991 Recent Economic Developments report (SM/91/183) explains on page 18 that: "In March Congress adopted a tax package that included increases in agricultural income taxes and in several excise taxes; an increase in tax payments by public enterprises, including special levies; the creation of a tax on real estate transfers; a one-year, 1 percentage point rise in the maximum value-added tax rate (later extended for another six months); and a temporary surcharge on certain imports".

The 1990 Request for Stand-by Arrangement document (EBS/90/202) presents on page 8 an estimate of the impact of the tax measures: "The revenue increase (equivalent to 1.7 percentage points of GDP) would result mainly from the measures adopted in March-April

\footnotetext{
${ }^{23}$ A tax reform motivated by long-run considerations was implemented in July 2007, but with an overall neutral impact on revenues and therefore it was not included in the database. The reform introduced a personal income tax and broadened the VAT tax base, but reduced corporate income taxes and reduced the VAT rate from 23 to 22 percent. According to the 2007 Article IV report (IMF Country Report No. 08/45), page 16: “... And, while the recently approved tax reform is expected to improve the efficiency of the system, the tax burden is projected to remain largely unchanged." See also the report for the ex-post evaluation of the SBA (IMF Country Report 08/47) page 19 and the report for the 5th and 6th Reviews of the SBA (EBS/06/166) page 15.

Gunter, Riera-Crichton, Vegh, and Vuletin (2017) consider the 1 percentage point reduction in the VAT to be exogenous driven by long-run considerations. While we agree with their assessment of the motivation of the policy actions, we believe that when the complete tax package is taken in to account (beyond the mere decrease in the statutory VAT rate), the policy record does not suggest a significant budgetary impact of the actions. The staff report for the 2008 Article IV consultation on page 29 Table shows 3 shows that revenues from VAT and excise taxes decreased by 0.1 percentage points of GDP in 2007, while overall tax revenue increased by 0.9 percent of GDP. This was accompanied by an increase in primary expenditures of 2.2 percent of GDP (especially wages by 1 percent of GDP).
} 
1990, supported by the efforts that are under way to reduce smuggling and tax evasion and to improve the efficiency of collections".

Table 2 on page 14 of the 1995 Article IV staff report (SM/95/126) contains historical data on actual expenditure measures implemented. It suggests that the budgetary impact of the expenditure cuts in investment and on the wage bill was more than offset by expenditure increases elsewhere.

\section{Uruguay 1995}

Fiscal consolidation amounted to 1.6 percent of GDP with expenditure cuts of 0.9 percent of GDP and tax hikes of 0.75 percent of GDP. The measures were motivated by the need to reduce the deficit. The 1995 Article IV staff report (SM/95/126) states on page 5 that: "The new Administration aims to improve growth performance in the medium-term by lowering inflation to industrial country levels and removing structural impediments to growth, while maintaining balance of payments viability. In the near term, the authorities are implementing a program based on a substantial reduction in the public sector deficit, together with monetary and wage restraint, to bring down inflation to 30 percent during 1995/96 (i.e., the year ending in March 1996), consistent with the maintenance of the current exchange rate policy".

Page 6 of the same report claims that ${ }^{24}$ : "Fiscal policy aims at lowering the public sector deficit from 31/4 percent of GDP in 1994 to 1 percent of GDP in 1995/96. Measures have been taken to restrain the growth of expenditures, including curtailing hiring in the public sector, limiting discretionary expenditures on goods and services to levels that would reduce them by 10 percent in real terms relative to the previous year's level, and reducing capital expenditures by 1 1 $\frac{1}{2}$ percentage points of GDP from the relatively high level in 1994. Congress recently approved measures that would strengthen the public finances by the equivalent of over 1 percent of GDP in the program year. Tax measures include: an increase in the basic rate of the value added tax (VAT) from 22 percent to 23 percent and in the lower VAT rate from 12 percent to 14 percent, while reducing VAT exemptions; an increase in the rates of the tax on wages and retirement pensions; and various changes in the corporate income, agricultural and sales taxes to strengthen collections. The effect of these tax measures would be offset in part by a reduction of employer social security contribution rates in the manufacturing sector and an increase in family allowances for low income families".

The 1996 Article IV consultation staff report (EBS/96/115) states on page 2 that: "The Central Administration wage bill and outlays on goods and services were restrained, and investment spending was scaled back relative to GDP from the relatively high levels recorded in 1994 and early 1995; however, social security outlays increased as inflation

\footnotetext{
${ }^{24}$ Note that targets were set for 1995/96 in the discussion in the text because authorities had elaborated a program for the period up to March 1996 that was monitored informally by IMF staff.
} 
declined (by constitutional mandate, pensions are indexed to past average take-home wages). A tax package was implemented in May 1995 (broadening tax coverage and raising the rates of the value added tax (VAT) and the personal tax on wages and pensions (IRP)), employer social security contribution rates for the manufacturing sector were reduced by 6 percentage points in July 1995, and public enterprise tariffs and prices were increased significantly during the year. Although the net revenue effect of the tax measures was positive, tax revenue fell relative to GDP in 1995 reflecting the sharp fall in domestic demand".

Gunter, Riera-Crichton, Vegh, and Vuletin (2017) identify the one percentage point increase in the VAT rate as endogenous, on the basis that it was offset by other tax reductions. Nevertheless, the net revenue effect of the tax measures seems to have been positive (see above). In addition, the 1996 Recent Economic Developments report (SM/96/174) states on page 5 that: "In 1995, despite a sharp fall in domestic demand, indirect tax collection on domestic transactions increased by $1 / 3$ percentage point of GDP as VAT rates were increased (from 22 percent to 23 percent the basic rate, and from 12 percent to 14 percent the lower rate) in the middle of the year".

Based on the discussions above and on table 3 presented on page 17 of the 1996 Article IV consultation staff report (EBS/96/115), we assign a reduction in primary expenditures of 0.9 percent of GDP to 1995 (a 1.4 percent of GDP cut in capital expenditures partly offset by an increase of 0.5 percent in current expenditures). Moreover, we assign a revenue increase of 0.75 percent of GDP to 1995 and 0.25 percent to 1996 as the tax measures were expected to have an effect of around 1 percent of GDP over the program year (up to March 1996).

\section{Uruguay 1996}

The fiscal consolidation initiated in 1995 continued in 1996, with tax measures totaling 0.25 percent of GDP. Fiscal consolidation was motivated by the desire to reduce the deficit (see entry for 1995above).

\section{Uruguay 2000}

Fiscal consolidation consisted of expenditure cuts amounting to 0.8 percent of GDP. The measures were motived by long-run considerations. The 2001 Article IV staff report (EBS/01/17) states on page 3 that: "President Batlle of the Colorado party, heading a Colorado/Blanco government, took office on March 1, 2000. The government holds a small majority in Congress. The authorities are aiming for a significant strengthening of competitiveness in the economy through medium-term fiscal consolidation, and marketoriented structural reforms."

The 2001 Recent Economic Developments report (SM/01/26) states on page 37 that: "The new government that took office in March 2000 introduced spending cuts to reverse the deficit overrun from 1999, and the fiscal impulse swung from expansionary to contractionary 
in 2000". The 2003 Article IV staff report (EBS/03/93) has estimates of the size of spending cuts in table 7, page 30 . Virtually all of the adjustment was due to a reduction in capital expenditures.

\section{Uruguay 2002}

Fiscal consolidation consisted of 1.6 percent of GDP in tax measures and 1.7 percent of GDP in expenditure cuts. The consolidation package was motivated by the need to reduce debt. The measures were adopted in the context of a banking and balance of payments crisis and a severe economic recession. They were part of an IMF supported-program. A sharp exchange rate depreciation led to a deterioration in public debt dynamics and concerns over sustainability (see the 2003 Article IV consultation staff report IMF Country Report 03/247, page 11). Paragraph 8 of the June 2002 Memorandum of Economic and Financial Policies sheds light on the motivation for the adjustment: "The government is determined to ensure the sustainability of the public debt over the medium term and is taking steps to strengthen the public finances in spite of the more difficult conditions being faced by Uruguay. As envisaged in the original program, the government is seeking a permanent increase in the primary surplus, raising it from 1 percent of GDP in 2001 to around 4 percent by 2004 and beyond. This target should be adequate to begin to reduce the public debt to GDP ratio from 2004 onwards, even in the eventuality of higher interest rates, a more depreciated peso, and additional debt to assist the banking system".

The second SBA review staff report (IMF Country Report 03/116) mentions on page 4 two tax packages in February and May 2002, which included an increase in the tax on wages and pensions, new excise taxes, and a broadening of the VAT base. The full year effect of these measures was estimated to be about 2.1 percent of GDP (see paragraph 9 of the June 2002 Memorandum of Economic and Financial Policies). But some of the measures were only temporary and due to expire at the end of 2003, with an expected revenue loss of 1.2 percent of GDP (see paragraph 11 of the June 2002 Memorandum of Economic and Financial Policies). Due to the timing of the implementation of the tax packages, we assign a revenue effect of about 1.6 percent of GDP to $2002(0.75 * 2.1)$ and of 0.5 percent of GDP to 2003.

Primary expenditures were programmed to fall by 1.2 percent of GDP in 2012 (see paragraph 9 of the June 2002 Memorandum of Economic and Financial Policies). Table 6 on page 28 of the 2003 Article IV consultation staff report (IMF Country Report 03/247) confirms that significant expenditure cuts were implemented and exceed programmed targets, in particular as far as capital expenditures (which fell by 1.2 percent of GDP) and use of goods and services (which declined by 0.5 percent of GDP) were concerned.

\section{Uruguay 2003}

Fiscal consolidation consisted of 1.4 percent of GDP in revenue measures and 0.2 percent of GDP in expenditure cuts. The measures were motivated by the need to reduce debt. Paragraphs 1 and 2 of the February 2003 Memorandum of Economic and Financial 
Policies discuss the motivations for the fiscal actions in 2003: "Building on the 2002 program, the government has elaborated policies for 2003 aimed at creating the conditions for a resumption of economic growth while keeping inflation under control.... The key objectives of the program are to ensure fiscal, monetary, and banking soundness". The second SBA review (IMF Country Report 03/116) also discusses on page 7 the motivations for the program: "The authorities' economic program seeks to credibly improve public finances in 2003, and to provide the basis for a sound medium-term fiscal position."

On the revenue-side, authorities adopted measures to boost the operational surplus of public enterprises. Box 2 on page 8 of the second SBA review (IMF Country Report 03/116) states that tariff adjustments would improve revenues by 1.5 percent of GDP, whereas current expenditures were expected to increase by 0.6 percent of GDP. Therefore, we assign a net effect of these new measures of 0.9 percent of GDP. In addition, as explained in the entry for 2002 above, we assigned a revenue effect related to the 2002 revenue package of about 0.5 percent of GDP $(0.25 * 2.1)$ to 2003 .

The second SBA review (IMF Country Report 03/116) also states on page 7 that a newly established program for centralization of public sector procurement of medical supplies and food would yield expenditure savings in the order of 0.2 percent of GDP. In addition, Table 4 on page 31 of the $4^{\text {th }}$ SBA review staff report (IMF Country Report 04/172) also points to a large fall in social security benefits from 16.3 percent of GDP in 2002 to 13.9 percent of GDP in 2003. Nevertheless, this was mostly linked to the fact that these benefits were indexed to wages (which grew less than expected) rather than specific policy actions.

\section{Uruguay 2004}

Unwinding of surcharges and taxes that were introduced in 2002, amounting to a reduction in revenues of 0.5 percent of GDP. The $5^{\text {th }}$ SBA review staff report (IMF Country Report No. 04/327) states on page 8 that "Preliminary second-quarter data indicate that revenue has continued to outperform the program, mainly due to buoyant corporate income tax receipts, and expenditure restraint has been maintained. In light of this performance, in May-July, the authorities eliminated emergency surcharges (on the wage tax and corporate income tax) and taxes (on commissions and public utilities), which will cost the budget about 0.5 percent of GDP in 2004 (1.4 percent of GDP on an annual basis)". These measures had been introduced during the financial crisis in 2002 and at that time, the government was given the authority to unwind if prospects for achieving fiscal targets improved. Following the estimates presented in the report, we assign a reduction in revenues of 0.5 percent of GDP in 2004 and 0.9 percent of GDP to 2005.

\section{Uruguay 2005}

Tax cuts initiated in 2004 continued in 2005 , with a reduction in revenues totaling 0.9 percent of GDP. See entry for 2004 above. 


\section{Uruguay 2015}

Fiscal consolidation consisted of (capital) expenditure cuts of 0.6 percent of GDP. The measures were taken to reduce an inherited deficit and preserve fiscal sustainability, as discussed in the 2015 Article IV report (IMF Country Report 16/62 page 23): "The authorities reaffirmed their commitment to a reduction in the overall fiscal balance to 2.5 percent of GDP by 2019 and emphasized the possibility of revising the budget in 2017 to meet this objective." The statement by the executive director (page 4) in the same IMF country report also sheds light on the authorities motivations for the policy actions: "The current slowdown presents a number of macroeconomic challenges; the reduction of inflation (under control but, admittedly, at higher rates than envisaged), the preservation of competitiveness, maintaining a sustainable path of fiscal accounts, and the continuation of the soundness of financial stability constitute high priorities for the Uruguayan government. In order to attain them, the Central Bank has kept a firm contractionary monetary policy stance (as said, in the context of a flexible exchange rate system); the five-year budget envisages a reduction in the fiscal deficit and a sound trajectory of the public debt; the authorities are fully committed to improving the efficiency of public enterprises and, particularly, restoring the financial position of the public oil distribution company."

The Table on page 47 of the 2016 Informe económico - financiero Exposición de motivos elaborated by the Ministry of Finance indicates that revenues of the consolidated public sector remained broadly constant as a share of GDP in 2015. But primary expenditure fell by 0.6 percent of GDP, with a 0.9 percent of GDP cut in capital expenditure relative to 2014 partly offset by a 0.3 percent of GDP increase in current expenditure. 


\section{Descriptive Features OF THE NARRATIVE DATASET}

This section lists the budgetary impact of the narrative fiscal shocks and presents some descriptive statistics on the episodes identified using the narrative approach. The dataset contains 76 observations over the period 1989-2016, which are listed in terms of the budgetary impact of the fiscal policy action as a share of GDP in a given year.

We further classify the consolidation episodes as "tax-based" or "expenditure-based" depending on whether tax hikes or expenditure cuts account for most of the budgetary impact of the consolidation. In practical terms, we follow the literature and define "most" as greater than half of the total impact (Guajardo, Leigh, and Pescatori, 2014). In three cases: Costa Rica 2016; Jamaica 2003; and Jamaica 2004; the packages seem to be balanced between tax hikes and spending cuts, and therefore we do not classify them in either category. There are 55 observations for tax-based consolidations and 18 for expenditure-based ones.

The average consolidation size (excluding zero observations i.e. considering that a fiscal policy action occurred) is 0.9 percent of GDP with a standard deviation of about 1 percentage point (Table 1). Expenditure based consolidations are typically larger, although comparisons along this dimension should be made with care given the relatively small number of expenditure-based consolidations.

Table 1. Descriptive Statistics for Narrative Consolidations 1989-2016

\begin{tabular}{lccc}
\hline & All Consolidations & $\begin{array}{c}\text { Tax-Based } \\
\text { Consolidations }\end{array}$ & $\begin{array}{c}\text { Expenditure-Based } \\
\text { Consolidations }\end{array}$ \\
\hline Number of Observations & 76 & 55 & 18 \\
Mean (\% of GDP) & 0.91 & 0.79 & 1.18 \\
Median (\% of GDP) & 0.73 & 0.6 & 0.8 \\
Standard Deviation & 1.02 & 0.98 & 1.09 \\
Skewness & 0.96 & 0.95 & 1.10 \\
Kurtosis & 4.12 & 4.40 & 3.97 \\
\hline
\end{tabular}


Table 2. Budgetary Impact of Narrative Fiscal Shocks (\% of GDP)

\begin{tabular}{|c|c|c|c|c|}
\hline Country & Year & Total & Tax & Spend \\
\hline ARG & 1996 & 0.25 & 0.25 & 0.00 \\
\hline ARG & 1997 & 0.75 & 0.75 & 0.00 \\
\hline $\mathrm{BOL}$ & 1995 & 0.90 & 0.90 & 0.00 \\
\hline $\mathrm{BOL}$ & 2004 & 2.00 & 2.00 & 0.00 \\
\hline $\mathrm{BOL}$ & 2005 & 4.10 & 4.10 & 0.00 \\
\hline BRA & 2015 & 0.80 & 0.30 & 0.50 \\
\hline $\mathrm{CHL}$ & 1990 & 0.50 & 0.50 & 0.00 \\
\hline $\mathrm{CHL}$ & 1991 & 0.17 & 0.17 & 0.00 \\
\hline $\mathrm{CHL}$ & 2003 & 0.60 & 0.20 & 0.40 \\
\hline $\mathrm{CHL}$ & 2004 & 0.40 & 0.40 & 0.00 \\
\hline $\mathrm{CHL}$ & 2008 & -0.50 & 0.00 & -0.50 \\
\hline $\mathrm{CHL}$ & 2014 & 0.10 & 0.10 & 0.00 \\
\hline $\mathrm{CHL}$ & 2015 & 0.18 & 0.18 & 0.00 \\
\hline $\mathrm{CHL}$ & 2016 & 0.31 & 0.31 & 0.00 \\
\hline $\mathrm{COL}$ & 2000 & 0.90 & 0.00 & 0.90 \\
\hline $\mathrm{COL}$ & 2003 & 1.10 & 1.10 & 0.00 \\
\hline $\mathrm{COL}$ & 2011 & 0.40 & 0.40 & 0.00 \\
\hline $\mathrm{COL}$ & 2012 & 0.80 & 0.80 & 0.00 \\
\hline $\mathrm{COL}$ & 2015 & 0.50 & 0.00 & 0.50 \\
\hline $\mathrm{COL}$ & 2016 & 0.70 & 0.00 & 0.70 \\
\hline CRI & 1990 & 1.50 & 1.50 & 0.00 \\
\hline CRI & 1991 & 3.10 & 3.10 & 0.00 \\
\hline CRI & 1992 & 0.50 & 0.50 & 0.00 \\
\hline CRI & 1993 & -0.30 & -0.30 & 0.00 \\
\hline CRI & 1994 & -0.50 & -0.50 & 0.00 \\
\hline CRI & 1995 & 1.80 & 1.00 & 0.80 \\
\hline CRI & 1996 & 0.30 & 0.30 & 0.00 \\
\hline CRI & 1997 & 0.40 & 0.00 & 0.40 \\
\hline CRI & 2016 & 0.40 & 0.20 & 0.20 \\
\hline DOM & 2004 & 1.70 & 0.50 & 1.20 \\
\hline DOM & 2006 & -0.80 & -0.80 & 0.00 \\
\hline DOM & 2007 & 0.90 & 0.90 & 0.00 \\
\hline DOM & 2011 & 0.64 & 0.44 & 0.20 \\
\hline DOM & 2013 & 3.80 & 1.80 & 2.00 \\
\hline $\mathrm{ECU}$ & 1990 & 0.32 & 0.32 & 0.00 \\
\hline ECU & 1993 & 2.20 & 1.70 & 0.50 \\
\hline ECU & 2000 & 0.50 & 0.50 & 0.00 \\
\hline
\end{tabular}

Note: Table records budgetary impact of fiscal consolidation measures. Positive values indicate budgetary savings, negative values indicate budgetary costs. See text for details. $A R G=$ Argentina, $B O L=B o l i v i a, B R A$ $=$ Brazil, $\mathrm{CHL}=$ Chile, $\mathrm{COL}=$ Colombia, $\mathrm{CRI}=$ Costa Rica, $\mathrm{DOM}=$ Dominican Republic, $\mathrm{ECU}=$ Ecuador. 
Table 2 (cont.). Budgetary Impact of Narrative Fiscal Shocks (\% of GDP)

\begin{tabular}{|c|c|c|c|c|}
\hline Country & Year & Total & Tax & Spend \\
\hline GTM & 1995 & 0.80 & 0.80 & 0.00 \\
\hline GTM & 1996 & 0.70 & 0.70 & 0.00 \\
\hline GTM & 2000 & 1.30 & 0.30 & 1.00 \\
\hline GTM & 2002 & 1.90 & 1.00 & 0.90 \\
\hline GTM & 2012 & 0.40 & 0.00 & 0.40 \\
\hline GTM & 2013 & 1.00 & 1.00 & 0.00 \\
\hline MEX & 1989 & 0.90 & 0.90 & 0.00 \\
\hline MEX & 2010 & 0.60 & 0.60 & 0.00 \\
\hline MEX & 2014 & 0.60 & 0.60 & 0.00 \\
\hline PRY & 1989 & 2.60 & 2.00 & 0.60 \\
\hline PRY & 2001 & 1.80 & 0.50 & 1.30 \\
\hline PRY & 2003 & 1.25 & 1.25 & 0.00 \\
\hline PRY & 2004 & 0.80 & 0.80 & 0.00 \\
\hline PRY & 2005 & -0.60 & -0.60 & 0.00 \\
\hline PRY & 2006 & -0.70 & -0.70 & 0.00 \\
\hline PRY & 2014 & 0.24 & 0.24 & 0.00 \\
\hline PRY & 2016 & 0.80 & 0.00 & 0.80 \\
\hline PER & 1992 & 1.00 & 1.00 & 0.00 \\
\hline PER & 2002 & 0.20 & 0.20 & 0.00 \\
\hline PER & 2003 & 0.80 & 0.80 & 0.00 \\
\hline PER & 2011 & -0.38 & -0.38 & 0.00 \\
\hline PER & 2012 & 0.38 & 0.38 & 0.00 \\
\hline URY & 1990 & 1.70 & 1.70 & 0.00 \\
\hline URY & 1995 & 1.65 & 0.75 & 0.90 \\
\hline URY & 1996 & 0.25 & 0.25 & 0.00 \\
\hline URY & 2000 & 0.80 & 0.00 & 0.80 \\
\hline URY & 2002 & 3.27 & 1.58 & 1.70 \\
\hline URY & 2003 & 1.63 & 1.42 & 0.20 \\
\hline URY & 2004 & -0.50 & -0.50 & 0.00 \\
\hline URY & 2005 & -0.90 & -0.90 & 0.00 \\
\hline URY & 2015 & 0.60 & 0.00 & 0.60 \\
\hline JAM & 1992 & 2.10 & 2.10 & 0.00 \\
\hline JAM & 1999 & 0.70 & 0.00 & 0.70 \\
\hline JAM & 2000 & 1.80 & 0.00 & 1.80 \\
\hline JAM & 2003 & 3.00 & 1.50 & 1.50 \\
\hline JAM & 2004 & 1.00 & 0.50 & 0.50 \\
\hline JAM & 2012 & 0.80 & 0.80 & 0.00 \\
\hline JAM & 2013 & 2.60 & 2.00 & 0.60 \\
\hline JAM & 2014 & 0.60 & 0.40 & 0.20 \\
\hline
\end{tabular}

Note: GTM = Guatemala, MEX = Mexico, PRY = Paraguay, PER = Peru, URY = Uruguay, JAM = Jamaica 


\section{References}

Carrière-Swallow, Yan, David, Antonio C. and Leigh, Daniel, 2018. "The Macroeconomic Effects of Fiscal Consolidations in Developing Economies: Evidence from Latin America and the Caribbean", mimeo, International Monetary Fund.

David, Antonio C. 2017. "Fiscal Policy Effectiveness in a Small Open Economy: Estimates of Tax and Spending Multipliers in Paraguay", IMF Working Paper 17/63 (Washington: International Monetary Fund).

Devries, Pete, Guajardo, Jaime, Leigh, Daniel and Pescatori, Andrea 2011. "A New ActionBased Dataset of Fiscal Consolidation” IMF Working Paper 11/128 (Washington: International Monetary Fund).

Escolano, Julio, Jaramillo, Laura, Mulas-Granados, Carlos and Terrier, Gilbert, 2014. "How Much is A Lot? Historical Evidence on the Size of Fiscal Adjustments" IMF Working Paper 14/179 (Washington: International Monetary Fund).

Guajardo, Jaime, Leigh, Daniel and Pescatori, Andrea, 2014. "Expansionary Austerity? International Evidence" Journal of the European Economic Association 12: 949-968.

Gunter, Samara, Riera-Crichton, Daniel, Vegh, Carlos A., and Vuletin, Guillermo, 2017. "Non-linear effects of tax changes on output: A worldwide narrative approach", IDB Discussion Paper IDP-DP-540 (Washington: Inter-American Development Bank).

Jordà, Òscar, and Taylor, Alan, 2015. "The Time for Austerity: Estimating the Average Treatment Effect of Fiscal Policy," Economic Journal 126: 219-55.

Liu, Estelle X., Mattina, Todd, and Poghosyan, Tigran, 2015. "Correcting "Beyond the Cycle: Accounting for Asset Prices in Structural Fiscal Balances”, IMF Working Paper 15/109. (Washington: International Monetary Fund).

Ramey, Valerie, 2016. "Macroeconomic Shocks and Their Propagation," Working paper 21978 (Cambridge: National Bureau of Economic Research).

Romer, Christina and Romer, David, 2010. "The Macroeconomic Effects of Tax Changes: Estimates Based on a New Measure of Fiscal Shocks." The American Economic Review 100: 763-801.

Yang, Weonho, Fidrmuc, Jan, and Ghosh, Sugata, 2015. "Macroeconomic Effects of Fiscal Adjustment: A Tale of Two Approaches", Journal of International Money and Finance 57: 31-60. 